\title{
Does Corporate Social Responsibility Affect the Cost of Capital? *
}

\author{
Sadok El Ghoul \\ University of Alberta, Edmonton, AB T6C 4G9, Canada \\ elghoul@ualberta.ca \\ Omrane Guedhami \\ Moore School of Business, University of South Carolina, Columbia, SC 29208, USA \\ omrane.guedhami@moore.sc.edu \\ Chuck C. Y. Kwok \\ Moore School of Business, University of South Carolina, Columbia, SC 29208, USA \\ ckwok@moore.sc.edu \\ Dev Mishra \\ University of Saskatchewan, Saskatoon, SK S7N 4M5, Canada \\ mishra@edwards.usask.ca
}

\begin{abstract}
We examine the effect of corporate social responsibility (CSR) on the cost of equity capital for a large sample of U.S. firms. Using several approaches to estimate firms' ex ante cost of equity, we find that firms with better CSR scores exhibit cheaper equity financing. In particular, our findings suggest that investment in improving responsible employee relations, environmental policies, and product strategies contributes substantially to reducing firms' cost of equity. Our results also show that participation in two "sin" industries, namely, tobacco and nuclear power, increases firms' cost of equity. These findings support arguments in the literature that firms with socially responsible practices have higher valuation and lower risk.
\end{abstract}

July 2010

JEL classification: G32, G34, M14

Keywords: Corporate social responsibility, Cost of equity capital

* We thank Najah Attig, Narjess Boubakri, Jean-Marie Gagnon, Oumar Sy, participants at the 2010 Academy of International Business Meeting, and especially an anonymous referee for their comments. We acknowledge generous financial support from Canada's Social Sciences and Humanities Research Council. 


\title{
Does Corporate Social Responsibility Affect the Cost of Capital?
}

\begin{abstract}
We examine the effect of corporate social responsibility (CSR) on the cost of equity capital for a large sample of U.S. firms. Using several approaches to estimate firms' ex ante cost of equity, we find that firms with better CSR scores exhibit cheaper equity financing. In particular, our findings suggest that investment in improving responsible employee relations, environmental policies, and product strategies contributes substantially to reducing firms' cost of equity. Our results also show that participation in two "sin" industries, namely, tobacco and nuclear power, increases firms' cost of equity. These findings support arguments in the literature that firms with socially responsible practices have higher valuation and lower risk.
\end{abstract}

July 2010

JEL classification: G32, G34, M14

Keywords: Corporate social responsibility, Cost of equity capital 


\section{Introduction}

Corporate social responsibility (CSR) has become increasingly important in recent years owing to the dramatic growth in the number of institutes, mutual funds, and online resources and other publications that specialize in encouraging corporations to improve their practices according to various responsibility criteria (Bassen et al., 2006). ${ }^{1}$ To cope with the increased attention given to corporations' impact on society, more than half of the Fortune 1,000 companies in the U.S. regularly issue CSR reports, and nearly $10 \%$ of U.S. investments are screened to ensure that they meet CSR-related criteria (Galema et al., 2008). Moreover, a growing number of firms worldwide have undertaken serious efforts to integrate CSR into various aspects of their businesses (Harjoto and Jo, 2007). ${ }^{2}$

As summarized in Robinson et al. (2008), numerous theoretical arguments have been put forward to explain why CSR activities may enhance firm value. For instance, McGuire et al. (1988) argue that a perceived decline in CSR may lead investors to increase explicit claims on the firm, whereas an increase in perceived CSR may improve a firm's reputation and thus permit it to swap costly explicit claims for less costly implicit charges. Fombrun and Shanely (1990) suggest further that building a positive reputation in the product and labor markets can generate subsequent benefits by allowing companies to charge customers premium prices and by attracting better job applicants. Customers are likely to pay premium prices for products from high-reputation firms, thereby increasing revenues, because reputation serves as a signal of product quality. Similarly, because employees generally prefer to work for firms with a good reputation, they are likely to either work harder or accept lower compensation, thereby

${ }^{1}$ How is CSR defined? Hill et al. (2007) define corporate social responsibility as the economic, legal, moral, and philanthropic actions of firms that influence the quality of life of relevant stakeholders. The World Bank Council for Sustainable Development defines CSR as "the continuing commitment by business to behave ethically and contribute to economic development while improving the quality of life of the workforce and their families as well as of the local community and society at large." While the definition of CSR may vary across organizations, it generally refers to "actions that appear to further some social good, beyond the interests of the firm and that which is required by law" (McWilliams and Siegel, 2001, p. 117).

${ }^{2}$ In her keynote speech to the Eastern Financial Association, Starks (2009) described a new acronym that has been developed to capture a company's corporate social responsibility activities: ESG (environmental, social, and governance). Starks referred to a 2006 survey conducted by Mercer Consulting in which investors were asked how important they viewed various ESG factors to be for investment. The percentage of survey respondents indicating that these factors were very important were, respectively, corporate governance $(64 \%)$, sustainability $(39 \%)$, employee relations $(33 \%)$, human rights $(26 \%)$, water (25\%), environmental management (18\%), and climate change $(7 \%)$. 
reducing the firm's costs (Roberts and Dowling, 2002). Taken together, this thread of the literature suggests that CSR can increase firm value through positive reputation effects.

However, CSR activities may not always be value-increasing. For instance, a firm that invests in pollution-control equipment while its rivals do not may be putting itself at a competitive disadvantage (Waddock and Graves, 1997). Agency issues may exacerbate this problem as corporate executives may seek to enhance their public image and pursue other private benefits at the expense of shareholders. For instance, Brown et al. (2006) find that agency costs play a major role in corporate philanthropic practices. They document that firms with larger boards of directors give more cash to charities and are more likely to establish corporate foundations.

Apart from the theoretical arguments, researchers have empirically examined the extent to which firm CSR activities are value-increasing, decreasing, or neutral. The results are mixed. For instance, Feldman et al. (1997) find that investors perceive firms with better environmental performance as less risky. Alternatively, Brammer et al. (2006) find that firms with higher social performance scores achieve lower returns. However, Hamilton et al. (1993) find that the excess returns of socially responsible mutual funds do not differ statistically from those of conventional mutual funds. Nelling and Webb (2009) also find no evidence that CSR activities affect financial performance.

After reviewing a number of CSR studies, Renneboog et al. (2008) conclude that whether CSR is priced by capital markets remains an open question. They thus join previous calls for research that directly examines how CSR influences firms' cost of equity capital (e.g., Kempf and Osthoff, 2007). In this paper we seek to answer this call. Building on the theoretical frameworks of Merton (1987) and Heinkel et al. (2001), we hypothesize that ceteris paribus, high CSR firms have lower cost of equity capital than low CSR firms owing to low CSR firms being associated with a smaller investor base and higher perceived risks. To compute firms' cost of equity capital, we follow an increasing number of studies in accounting and finance (e.g., Hail and Leuz, 2006; Chen et al., 2009a) and use the ex ante cost of equity implied in analyst earnings forecasts and stock prices. This accounting-based approach offers two main advantages. First, unlike traditional measures of firm value (e.g., Tobin's Q), it allows one to control for differences in growth rates and expected future cash flows when estimating firms' cost of equity 
(Hail and Leuz, 2006). Second, it circumvents the failure of traditional asset pricing models to deliver accurate estimates of firm-level cost of equity capital as well as the use of noisy realized returns (Pástor et al., 2008). Additionally, the cost of equity represents investors' required rate of return on corporate investments and thus is a key input in firms' long-term investment decisions. Examining the link between CSR and the cost of equity should therefore help managers understand the effect of CSR investment on firms' financing costs, and hence has important implications for strategic planning. Indeed, the cost of capital could be the channel through which financial markets encourage firms to become socially more responsible (e.g., Heinkel et al., 2001).

Using a sample of 12,915 U.S. firm-year observations from 1992 to 2007, we find that firms with a better CSR score exhibit lower cost of equity capital after controlling for other firmspecific determinants as well as industry and year fixed effects. Moreover, we find that CSR investment in improving responsible employee relations, environmental policies, and product strategies substantially contributes to reducing firms' cost of equity. We also show that firms related to two "sin" business sectors, namely, tobacco and nuclear power, appear to observe higher equity financing costs. Our evidence is robust to a battery of sensitivity tests, including alternative assumptions and model specifications, additional controls for noise in analyst forecasts and corporate governance, and various approaches to address endogeneity. Our findings therefore support arguments in the literature that CSR enhances firm value.

Our study contributes to the literature in several ways. First, while previous studies investigate whether CSR affects firm value, this is the first study to our knowledge to use a large panel of U.S. firms to examine the effect of CSR on the ex ante cost of equity capital. Our investigation is motivated by prior research suggesting that an important mechanism through which CSR affects firm value is its effects on firm risk (e.g., Spicer, 1978; McGuire et al., 1988; Starks, 2009). Our empirical findings provide supportive evidence. Second, we extend prior research that shows that firms with better corporate governance ratings enjoy lower equity financing costs (e.g., Chen et al., 2009a; Guedhami and Mishra, 2009). In particular, our finding that the impact of CSR continues to hold even after controlling for firm-level corporate governance suggests that firms are likely to benefit from improving not only their corporate governance, but also their social responsibility. Third, using a more direct proxy of expected returns, we confirm the findings of Hong and Kacperczyk (2009) that "sin" stocks generally 
have higher expected returns as they are less preferred by norm-constrained investors and are more likely to face greater litigation risk. Our results suggest that, among the "sin" stocks, firms related to the tobacco and nuclear power industries have a significantly higher cost of equity capital.

The remainder of the paper is organized as follows. Section 2 motivates how a firm's CSR activities may affect its cost of equity capital. Section 3 describes our sample and discusses the regression variables. Section 4 presents the empirical evidence. Section 5 concludes the paper.

\section{Corporate Social Responsibility and Cost of Equity Capital}

In this section, we provide theoretical arguments motivating our expectation that ceteris paribus, the cost of equity capital is lower for high CSR firms than low CSR firms. The arguments involve: i) the relative size of a firm's investor base, and ii) a firm's perceived risk.

\subsection{Relative Size of a Firm's Investor Base}

The capital market equilibrium model of Merton (1987, p. 500) implies that increasing the relative size of a firm's investor base will result in lower cost of capital and higher market value for the firm. In a similar vein, Heinkel et al. (2001) develop an equilibrium model that implies that when fewer investors hold the stock of a firm, the opportunities for risk diversification are reduced and hence the firm's cost of capital will be higher. In this paper, we argue that low CSR firms tend to have smaller investor base due to investor preferences and information asymmetry.

First, with respect to investor preferences, prior work argues that socially conscious investors prefer not to include low CSR firms in their investment portfolios. For instance, based on their equilibrium model, Heinkel et al. (2001) argue theoretically that exclusionary investing by green investors leads polluting firms to be held only by neutral, and thus fewer, investors. As a result, polluting firms have to offer neutral investors higher expected returns to compensate them for the lack of risk sharing. Empirically, Hong and Kacperczyk (2009) study "sin" stocks, i.e., publicly listed firms operating in the alcohol, tobacco, and gaming industries, 
and find that norm-constrained institutional investors (e.g., pension plans) include fewer "sin" stocks in their portfolios compared to arbitrageurs (e.g., mutual or hedge funds).

Second, with respect to information asymmetry, we argue that information asymmetry is likely to be more severe for low CSR firms. Departing from the traditional perfect markets model, which assumes that information is complete and instantaneous, Merton (1987) develops a capital market equilibrium model that allows for incomplete information. In particular, Merton's model relies on the behavioral assumption that, in constructing his optimal portfolio, an investor takes security $k$ into account only if he knows about security $k$. Merton explains that for information to be transmitted from firm $k$ to the investor, certain costs are incurred, for example, the cost of gathering and processing data and the cost of transmitting information from one party to another (p. 489). Following Merton's analysis, we can break the information transmission process down into three parts: a) signaling by the firm; b) coverage by the media and analysts; and c) reception by investors. Dhaliwal et al. (2009) show empirically that high CSR firms tend to disclose more information, as these firms want to project their positive image as a responsible corporate citizen to investors and other stakeholders. Furthermore, Hong and Kacperczyk (2009) find that "sin" firms receive less coverage from analysts, which implies that analysts and the media are more inclined to spend time analyzing and reporting news about "good" firms. Finally, when information reaches investors, socially conscious investors are likely to pay more attention to information related to high CSR firms while neglecting information related to low CSR firms.

\subsection{A Firm's Perceived Risk}

Prior work suggests that investors perceive socially irresponsible firms as having a higher level of risk (Frederick, 1995; King, 1995; Robinson et al., 2008; Starks, 2009). Waddock and Graves (1997) argue that socially irresponsible firms may face uncertain future explicit claims. For example, if a firm does not invest in product safety and sells an unsafe product, this will increase the chance of future lawsuits against the firm and in turn the firm's expected future costs. Hong and Kacperczyk (2009) further argue that "sin" firms face higher litigation risks. As an illustration, they point to the case of tobacco companies, which faced substantial litigation risk until they reached a settlement with state governments in 1997. Feldman et al. (1997) find supportive evidence. In particular, they show that firms adopting a more 
environmentally pro-active posture experience a significant reduction in perceived riskiness to investors.

The question that remains is whether low CSR firms' higher perceived risks can be diversified away in an investor's portfolio and therefore not be priced in the cost of capital. As discussed in Section 2.1, socially conscious investors prefer not to invest in low CSR firms. Hong and Kacperczyk (2009, p. 17) stress that an implication of Merton's model is that idiosyncratic risk - and not just beta - matters for pricing because of either neglect or limited risk sharing. With a higher level of non-diversifiable risk, low CSR firms will thus face a higher cost of equity capital.

Based on the aforementioned arguments, we hypothesize that ceteris paribus, high CSR firms have lower cost of equity capital than low CSR firms.

\section{Data and Variables}

\subsection{Sample Construction}

To examine the relation between CSR and the cost of equity financing, we begin by merging four databases: Thompson Institutional Brokers Earnings Services (I/B/E/S), which provides analyst forecast data, Compustat North America, which provides industry affiliation and financial data, KLD STATS (created and maintained by KLD Research \& Analytics, Inc. (KLD)), which provides CSR data, and CRSP monthly return files, which provide information on stock returns. We follow Gebhardt et al. (2001) and Dhaliwal et al. (2006) and estimate the cost of equity in June of each year. To do so, we extract from the I/B/E/S summary file forecast data recorded in June for all firms that have positive one- and two-year-ahead consensus earnings forecasts and a positive long-term growth forecast. For these firms, we further require that I/B/E/S provide a share price as of June, that Compustat report a positive book value per share, and that the firm belong to one of the Fama and French (1997) 48 industries. We then follow Hail and Leuz (2006) and Dhaliwal et al. (2006) and estimate the cost of equity capital using four models. These models are discussed below and summarized in Appendix A. Finally, we retain in our sample firms with valid cost of equity estimates under all four models and with sufficient available data to construct the CSR and control variables. This procedure yields a final 
sample of 12,915 observations representing 2,809 unique firms between 1992 and 2007.3 Table 1 summarizes the sample composition by Fama and French (1997) 48 industry groups (Panel A) and by year (Panel B). The banking, business services, electronic equipment, and utilities industries dominate the sample, with each accounting for more than $5 \%$ of the observations. Reflecting the enhanced coverage of firms in KLD STATS over time, the number of observations has increased over the sample period with a peak in $2004 .^{4}$

\subsection{Regression Variables}

\subsubsection{Cost of Equity Capital}

We follow recent research in accounting and finance to estimate the ex ante cost of equity implied in current stock prices and analyst forecasts. ${ }^{5}$ This design choice is motivated by prior research. Fama and French (1997) show that both the standard single-factor model and the Fama and French (1993) three-factor model provide poor proxies for the cost of equity capital. Elton (1999) raises additional concerns about conventional proxies for realized returns and hence calls for alternative proxies for expected returns. Hail and Leuz $(2006,2009)$ and Chen et al. (2009a) argue that the implied cost of capital approach is particularly useful because it makes an explicit attempt to isolate cost of capital effects from growth and cash flow effects. Pástor et al. (2008) provide consistent evidence, showing that the class of implied cost of capital models reasonably captures the time-variation in expected returns.

Although prior research proposes various models to calculate firms' implied cost of equity capital, to date it provides little guidance on the relative performance of these models. We therefore follow Hail and Leuz (2006) and estimate the cost of equity using four different models: the Claus and Thomas model (2001, CT), the Gebhardt et al. model (2001, GLS), the

${ }^{3}$ The final sample comprises $62 \%$ of the firm-year observations represented in the KLD database.

${ }^{4}$ In 2003, KLD added the Russel 2000 index and the Broad Market Social Index to KLD STATS.

5 The implied cost of capital approach has been used to examine the effects of, for example, legal institutions and securities regulations (Hail and Leuz, 2006), disclosure and earnings quality (Francis et al., 2005), dividends and taxes (Dhaliwal et al., 2006), tax enforcement (El Ghoul et al., 2010), corporate governance (Chen et al., 2009a,b), and ownership structure (Attig et al., 2008; Guedhami and Mishra, 2009; Boubakri et al., 2010), and has also been used in event studies that examine cross-listings (Hail and Leuz, 2009) and earnings restatements (Hirbar and Jenkins, 2004). 
Ohlson and Juettner-Nauroth model (2005, OJ), and the Easton model (2004, ES). ${ }^{6}$ Then, in line with Dhaliwal et al. (2006) and Chen et al. (2009b), we subtract the ten-year U.S. Treasury bond yield from the estimated cost of equity of each model. We denote the resulting cost of equity premiums as $r_{C T}, r_{G L S}, r_{O J}$, and $r_{E S}$, respectively. Appendix A provides details on the implementation of the four models. $r_{O J}$ is estimated in closed form. For the three other models, we employ numerical techniques to search for $r_{C T}, r_{G L S}$, and $r_{E S}$ while restricting the solution to be between $0 \%$ and $100 \%$. To reduce the possibility of spurious results associated with the use of a particular model (Dhaliwal et al., 2006), we compute the average cost of equity premium based on the four models. This yields $r_{A V G}$, which is the implied equity risk premium that we use as our dependent variable. Note that we use the terms equity premium and cost of equity interchangeably in the rest of this paper.

Table 2 reports descriptive statistics for the implied cost of equity premium. Panel A shows the equity premium estimates based on the four models. The average estimate across the four models is $4.75 \%$. The ES and OJ models produce higher average equity premiums (5.71\% and $5.61 \%$, respectively) compared to the CT and GLS models (3.92\% and 3.76\%, respectively). These figures are consistent with Dhaliwal et al. (2006) and Gode and Mohanram (2003), who show that the GLS model provides a lower bound and the OJ model often provides an upper bound for the implied cost of equity estimates. Panel B reports Pearson correlation coefficients between the four models' cost of equity estimates and our ultimate measure of the cost of equity capital $\left(r_{A V G}\right)$. Consistent with Dhaliwal et al. (2006), we find that $r_{O J}$ and $r_{E S}$ exhibit higher correlations with $r_{A V G}$, while $r_{C T}$ and $r_{G L S}$ exhibit lower correlations with $r_{A V G}$.

\subsubsection{Corporate Social Responsibility}

To specify our proxy for CSR, we rely on KLD STATS, which is a statistical summary of KLD's in-depth research. Founded in 1988, KLD is an independent firm that has been providing research and consulting services to investors interested in integrating social responsibility features into their investment decisions. KLD STATS contains ratings on a wide range of CSRrelated items compiled from various sources such as government agencies, non-governmental

\footnotetext{
${ }^{6}$ Evaluating which model is best is beyond the scope of our paper. In the sensitivity analyses, however, we examine whether our findings are robust to using each individual implied cost of equity model and to alternative approaches to estimating the cost of equity.
} 
organizations, global media publications, annual reports, regulatory filings, proxy statements, and company disclosures. Firm coverage in KLD STATS has increased steadily over time. During the 1991-2000 period, coverage consisted of the S\&P 500 and the Domini Social Index. Since then, KLD has sequentially added the Russell 1000 Index (in 2001), the Large Cap Social Index (in 2002), and both the Russell 2000 Index and the Broad Market Social Index (in 2003).

KLD STATS organizes the various CSR-related items into two major categories: qualitative issue areas and controversial business issues. Qualitative issue areas include: the community, corporate governance, diversity, employee relations, the environment, human rights, and product characteristics. For each qualitative issue area, KLD assigns a binary $(0 / 1)$ rating to a set of concerns and strengths as illustrated in Panel A of Appendix B. Controversial business issues include: alcohol, gambling, tobacco, firearms, the military, and nuclear power. For each controversial business issue, KLD assigns a binary (0/1) rating for whether a firm is involved in (at least one of) a set of concerns as illustrated in Panel B of Appendix B. We capture a firm's involvement in controversial business issues with a dummy variable that takes the value of 1 if a firm is involved in any of the six controversial business areas (CSR_CONTR). Because qualitative issue areas and controversial business issues are inherently different, we examine them separately. We calculate a score for each qualitative issue area equal to the number of strengths minus the number of concerns. We then sum the qualitative issue areas' scores to obtain an overall CSR score (CSR_S). In estimating CSR_S, we exclude corporate governance as our definition of CSR does not include conflicts of interest between insiders and shareholders. Nonetheless, in robustness tests we show that our inferences remain unchanged if we include corporate governance.

\subsubsection{Control Variables}

In our multivariate analysis we follow prior studies (e.g., Hail and Leuz, 2006; Gebhardt et al., 2001; Dhaliwal et al., 2006) in specifying controls shown to affect the cost of equity capital. These controls include: beta (BETA), estimated using the market model; ${ }^{7}$ size (SIZE), measured

\footnotetext{
7 We estimate BETA by regressing 60 monthly excess stock returns ending in June of year $t$ on the corresponding monthly CRSP value-weighted index excess returns. Monthly excess returns are monthly returns minus the one-month Treasury bill rate obtained from Professor Ken French's website (http://mba.tuck.dartmouth.edu/pages/faculty/ken.french/data_library.html). In these estimations, we require a minimum of 24 months of observations.
} 
as the natural logarithm of total assets; the book-to-market ratio (BTM); and leverage (LEV), computed as the ratio of total debt to the market value of equity. According to prior research, the predicted signs of these controls are as follows: BETA (+), SIZE (-), BTM (+), and LEV (+). ${ }^{8}$ In addition, we control for analyst forecast attributes, where we use both forecast dispersion $(D I S P)$, measured as the coefficient of variation of one-year-ahead earnings forecasts, ${ }^{9}$ and the consensus long-term growth forecast (LTG). Given the evidence in Gode and Mohanram (2003), Dhaliwal et al. (2006), and Guedhami and Mishra (2009), we expect these two variables to be positively related to the cost of equity. Finally, we control for year and industry effects using Fama-French (1997) 48 industry groups. All variables are defined in Appendix C.

\subsection{Descriptive Statistics}

Table 3 provides descriptive statistics for the CSR variables. Panel A reports the statistical properties of the overall CSR score over time. This score exhibits large variation over time. However, the overall median is zero, suggesting a relatively balanced distribution of firms with negative and positive CSR performance. Panel B reports the frequency distribution of the controversial business issues and suggests that involvement in these controversial issues has decreased over time.

Table 4 reports descriptive statistics for the other explanatory variables (Panel A) and for the pairwise correlations (Panel B) between the cost of equity estimates and the regression variables. We find that our CSR proxy $\left(C S R \_S\right)$ is associated with a lower equity risk premium. Additionally, all of the explanatory variables show the expected relations with our dependent variable, $r_{A V G}$. Finally, we do not find high correlations between the explanatory variables, which suggests that multicollinearity is not a serious concern in our regressions.

\footnotetext{
8 These predictions reflect prior findings that: a firm's beta is positively associated with its expected stock returns (e.g., Sharpe, 1964, Lintner, 1965); larger firms attract wider media and analyst coverage, which reduces information asymmetry and the cost of equity capital (Bowen et al., 2008); higher book-to-market firms are expected to earn higher ex post returns (Fama and French, 1992); and levered firms earn higher subsequent stock returns (Modigliani and Miller, 1958; Fama and French, 1992).

${ }^{9}$ In our analysis, we include all firms for which we can estimate the cost of equity, irrespective of the number of analysts that provide forecasts of future earnings and growth. The quality of our models' cost of equity estimates, however, is likely to depend on the quality of earnings forecasts: a consensus forecast from several analysts is likely to provide a more accurate prediction of expected cash flows than the forecast of a single analyst. As a robustness check, we repeat our analysis after excluding firm-years covered by fewer than three analysts or fewer than five analysts. Our conclusions remain unchanged.
} 


\section{Empirical Results}

As we discuss in the introduction, despite increased academic interest in CSR, we still know very little about how CSR performance affects firm valuation. The purpose of our study is to address this gap in the literature by empirically examining the link between firms' CSR activities and their cost of equity capital. We proceed as follows. In Section 4.1 we perform univariate tests that compare the cost of equity of firms with a below-median CSR score against the cost of equity of firms with an above-median CSR score. Next, in Section 4.2 we conduct multivariate regression analysis in which we regress firms' cost of equity on a number of CSR proxies and control variables. In Section 4.3 we report the results of sensitivity tests.

\subsection{Univariate Analysis}

Our univariate analysis compares the mean (Table 5, Panel A) and median (Table 5, Panel B) cost of equity premiums $\left(r_{A V G}\right)$ of firms with low and high CSR scores based on the median CSR value. The mean (median) equity premium of firms with a high CSR score is $4.54 \%$ $(4.25 \%)$, while it is $5.10 \%(4.64 \%)$ for firms with a low CSR score. These results suggest that the mean (median) cost of equity for firms with a high CSR score is 56 (39) basis points lower than that for firms with a low CSR score. These differences are significant at the $1 \%$ level. We find similar evidence when we examine differences in means and medians using the four individual cost of equity estimates. These preliminary findings suggest that firms with better CSR ratings have significantly lower cost of equity.

\subsection{Multivariate Regression Analysis}

To examine the cost of capital effects of CSR, we regress the cost of equity premium $r_{a v g}$ on various CSR proxies and control variables using pooled cross-sectional time-series regressions with robust standard errors clustered at the firm level. Table 6 reports our main results. In each model, our dependent variable is the average equity premium, $r_{\text {avg. }}$ The explanatory variables include various CSR metrics, six firm-specific control variables, as well as year and industry fixed effects. Consistent with our univariate evidence in Table 5, the results show strong evidence of CSR effects on the cost of equity.

Our test variable in Models 1 through 6 is the overall CSR score (CSR_S). In Model 1, our basic regression, we examine the impact of CSR on the cost of equity capital while controlling 
for year and industry fixed effects. We find that the coefficient on CSR_S is negative and statistically significant at the $1 \%$ level, suggesting that firms showing better social responsibility have significantly lower cost of equity capital. This significant relation remains when we further include in Model 2 the additional firm-specific controls discussed above (BETA, SIZE, BTM, $L E V, L T G$, and DISP). ${ }^{10}$ Economically, the estimated coefficient in Model 2 implies that a onestandard deviation increase in CSR_S leads firms' equity premium to decrease, on average, by 10 basis points. ${ }^{11}$ We interpret this result as evidence that the cost of capital is an important channel through which the market prices CSR.

Next, we examine whether the documented relation between CSR and the cost of equity changes over time. Given the growth of socially responsible investing and increasing awareness among investors of risks related to CSR-related practices and violations, we would expect this relation to change over time. Accordingly, we partition the full sample period into four subperiods: 1992-1995 (Model 3), 1996-1999 (Model 4), 2000-2003 (Model 5), and 2004-2007 (Model 6). In Models 3 and 4, we find that the coefficient on CSR_S is negative but statistically insignificant. In contrast, we find that CSR_S loads negative and statistically significant (at the $5 \%$ level or better) in Models 5 and 6 . These sub-period results indicate that the inverse relation between CSR and firms' equity financing costs is more significant in recent years, which we interpret as consistent with an increase in investor awareness about socially responsible stocks over time.

In the rest of Table 6, we extend our analysis to examine the association between the cost of equity capital and individual components of the overall social performance score (CSR_S).12 Specifically, we look at the following six attributes: community relations (CSR_COM_S), diversity (CSR_DIV_S), employee relations (CSR_EMP_S), environmental performance $\left(C S R \_E N V \_S\right)$, human rights (CSR_HUM_S), and product characteristics (CSR_PRO_S). For

\footnotetext{
${ }^{10}$ Although we attempt to control for all common factors shown in prior research to affect the cost of equity capital, we note that all our inferences remain when we use various combinations of these control variables or when we separately drop each of these controls. Indeed, as explained below, one could argue that the cost of equity could be related to CSR through various economic channels, such as leverage.

11 This is comparable to the economic effect of firm risk (BETA) on the cost of equity as shown below.

12 Motivating our analysis, Galema et al. (2008) explain that aggregating various dimensions of CSR may lead to confounding effects of the individual dimensions of social responsibility.
} 
each attribute, we compute a yearly score similar to the aggregate CSR_S (i.e., to the number of strengths minus the number of concerns). Our empirical objective is to determine whether certain attributes are more important than others in affecting a firm's cost of equity capital. The regression results on the cost of capital effects of the six CSR attributes are presented in Models 7 through 12 in Table 6. The results suggest that not all six items are relevant.

Our test variable in Model 7 is community relations (CSR_COM_S). The coefficient on CSR_COM_S is negative, but statistically indistinguishable from zero. We obtain similar results when we focus in Model 8 on CSR_DIV_S, which measures a firm's net performance in promoting diversity. Model 11 also reveals that the human rights score (CSR_HUM_S) does not load significantly. These findings suggest that the social performance attributes community relations, diversity, and human rights do not affect firms' equity financing costs. In contrast, employee relations, environmental performance, and product strategies do appear to matter for firms' cost of capital. In Model 9, we find a negative and statistically significant relation (at the $5 \%$ level) between the cost of equity and a firm's standing in employee relations (CSR_EMP_S). Similarly, the environmental performance proxy CSR_ENV_S is negative and highly significant in Model 10 suggesting that the market discounts the cash flows of firms with good environmental performance. ${ }^{13}$ Model 12 also shows a negative and statistically significant relation between the cost of equity capital and a firm's standing in product characteristics, CSR_PRO_S. In summary, the results in Models 7 through 12 suggest that firms that exhibit superior performance with respect to employee relations, environmental policies, and product strategies enjoy lower financing costs. However, the social performance attributes community relations, diversity, and human rights appear not to affect firms' cost of equity capital.

To better isolate the effect of CSR on the cost of capital, in each of the regressions in Table 6 (except regression (1)) we include a host of firm-specific characteristics, including size, risk, book-to-market, and leverage. We generally find that these control variables enter the

\footnotetext{
${ }^{13}$ Recall that in the 2006 survey conducted by Mercer Consulting, the percentages of survey respondents who indicated that various CSR attributes are important to investment decisions are as follows: sustainability $(39 \%)$, employee relations $(33 \%)$, human rights $(26 \%)$, water $(25 \%)$, environmental management $(18 \%)$, and climate change $(7 \%)$. Our findings are generally consistent with their survey results, except that our coefficient on CSR_HUM_S is negative but insignificant.
} 
models with the expected signs, and all are statistically significant at the $1 \%$ level. ${ }^{14}$ In particular, the results show positive and significant coefficients for firm risk (BETA) and bookto-market (BTM), and a negative and significant coefficient for firm size (SIZE). Additionally, we find that consistent with Gode and Mohanram (2003) and Dhaliwal et al. (2006), firm leverage $(L E V)$ loads positive and significant across all models. Finally, also in line with prior studies (e.g., Dhaliwal et al., 2006), we find that the two analyst forecast variables, forecast dispersion $(D I S P)$ and the consensus long-term growth forecast (LTG), have significantly positive effects on the cost of equity. Our findings on the control variables therefore reveal that our cost of equity estimates exhibit the expected relations with common risk factors. Accordingly, the significant relations between our CSR metrics and the cost of equity in Table 6 imply that the market prices a firm's CSR along with the other risk factors.

As we discuss above, Hong and Kacperczyk (2009) find evidence that firms operating in "sin" industries (e.g., alcohol, tobacco, and gambling) are held less by norm-constrained institutions such as pension funds, receive less coverage from analysts, and have higher expected returns. Accordingly, in Table 7 we analyze the effects of involvement in six controversial business areas, namely, alcohol, gambling, tobacco, firearms, the military, and nuclear power. We specify a dummy variable for each controversial business area, which we separately include in Models 2 through 7. We start in Model 1 by including the dummy variable CSR_CONTR to identify firms involved in any of the six controversial business areas. The coefficient estimate on CSR_CONTR is positive and statistically significant at the $10 \%$ level, suggesting that, consistent with Hong and Kacperczyk, firms involved in "sin" industries have higher cost of equity capital. In Models 2 through 7, we further find that except for gambling involvement in Model 3 (CSR_GAM), the coefficients on all other dummy variables are positive, although the statistical significance varies across the controversial business areas. Specifically, we find that alcohol (CSR_ALC in Model 2), firearms (CSR_FIR in Model 5), and military (CSR_MIL in Model 6) involvement are not significantly related to the cost of equity capital,

14 These effects are also economically significant. For example, the estimated coefficients of BETA, BTM, $L E V, L T G$, and DISP in Model 2 of Table 6 indicate that a one-standard deviation increase in each of these variables, while other variables are held at their mean values, increases the equity premium by $11.8,52.5$, $56.9,25.1$, and 48.5 basis points, respectively. Additionally, the estimated coefficient of SIZE implies that a one-standard deviation increase in firm size is associated with an 18.7 basis point decline in equity premium. 
suggesting that these businesses are not perceived to affect a firm's risk profile. In contrast, we find that tobacco (CSR_TOB in Model 4) and nuclear power (CSR_NUC in Model 7) involvement are associated with significantly (at the $5 \%$ level or better) higher cost of equity capital. This suggests that the market perceives these two controversial business sectors to be riskier and thus assigns a higher risk premium to firms involved in these industries. Overall, these findings are consistent with the theoretical prediction that exclusionary investing by green investors reduces demand for the stock of firms with poor social responsibility, thus limiting the risk-sharing opportunities of investors holding these stocks and increasing their required rate of return (Heinkel et al., 2001).

To summarize, three main results emerge from the analysis in Tables 6 and 7. First, CSR is priced, and is associated with cheaper equity financing. Second, the only CSR attributes that affect equity pricing are employee relations, environmental performance, and product characteristics; all other attributes exhibit little or no significant impact on firms' cost of equity. Third, firms related to the tobacco and nuclear power industries have significantly higher cost of equity.

\subsection{Robustness Checks}

In this section, we run a battery of sensitivity tests to examine whether our core evidence in Table 6 (Model 2) that CSR decreases the cost of equity is robust to alternative assumptions and model specifications, noise in analyst forecasts, and endogeneity, among other sensitivity checks. Overall, the results from these sensitivity tests reported in Tables 8 through 11 are not materially different from those of the primary analysis.

Alternative Assumptions and Model Specifications. Above, we specify our dependent variable as the average cost of equity premium $\left(r_{A V G}\right)$ based on four widely used implied cost of equity models to mitigate spurious results arising from the use of a single model. Nevertheless, here we examine whether our core finding in Table 6 is sensitive to using the individual cost of equity premiums. Models 1 through 4 in Table 8 replicate our base model (Model 1, Table 6) after replacing the dependent variable $r_{A V G}$ with the individual risk premiums $r_{C T}, r_{G L S}, r_{O J}$, and $r_{E S}$, respectively. We find that the coefficient on CSR_S is generally negative and statistically significant. These results reinforce our earlier evidence that improved CSR results in cheaper equity financing. 
As detailed in Appendix A the implied cost of equity models employ various assumptions about earnings growth rates and forecast horizons. To mitigate concerns that the assumptions underlying these four models are driving our results, in the remainder of Table 8 we report results from re-estimating our baseline model after replacing $r_{A V G}$ with cost of equity estimates from alternative models. In Model 5, we use the equity premium estimate based on the finite horizon expected return model described in Gordon and Gordon (1997). In Models 6 and 7, we apply the Price-Earnings-Growth (PEG) model, which assumes no dividend payments, to estimate the equity premium using short-term earnings forecasts and longer-term forecasts, respectively. Finally, in Model 8 we measure the cost of equity using the earnings-toprice ratio following Francis et al. (2005). We find that across Models 5 to 8, CSR_S loads negative and statistically significant at the $1 \%$ level, reinforcing our earlier conclusion that CSR performance reduces the cost of equity capital.

Noise in Analyst Forecasts. Despite the growing body of literature using the implied cost of capital approach, recent research has criticized this approach on the grounds that analyst forecasts are poor proxies for the market's expectations of future earnings, resulting in biased estimates of the cost of equity. More specifically, prior studies distinguish two sources of noise associated with analyst forecasts. The first suggests that analyst forecasts are overly optimistic, which causes the implied cost of equity to be biased upward (e.g., Kothari, 2001; Easton and Sommers, 2007). We address this concern in three ways. First, we explicitly control for forecast optimism bias (FBIAS), measured as the difference between the one-year-ahead consensus earnings forecast and realized earnings deflated by the June-end stock price. The results, which are reported in Model 1 of Table 9, show that the coefficient on CSR_S is negative and significant at the $1 \%$ level $(t$-statistic $=-3.38)$ after we include FBIAS. In this regression we also find, as expected, that FBIAS is positively and significantly associated with the cost of equity. Second, we successively exclude the top $5 \%, 10 \%, 25 \%$, and $50 \%$ of the firm-year observations in the FBIAS distribution (i.e., highly optimistic earnings forecasts). The results reported in Models 2 through 5 show that CSR_S is negatively and significantly (at the 1\% level) related to the cost of equity. Third, we address optimism in long-term forecasts by successively excluding the top $5 \%, 10 \%, 25 \%$, and $50 \%$ of the firm-year observations in the LTG distribution. The results, reported in Models 6 through 9, corroborate our earlier findings. 
The second source of noise in analyst forecasts is associated with analysts' sluggishness - i.e., their tendency to react slowly to publicly available information (e.g., Ali et al., 1992). We confront this concern in Table 10 using two approaches. First, we follow Guay et al. (2005) and Hail and Leuz (2006) and re-estimate the implied cost of equity using January-end prices instead of June-end prices, which gives analysts extra time to update their forecasts by incorporating the information in recent price movements. The results of this approach, which appear in Model 1, suggest that the negative and statistically significant effect of CSR on the cost of equity continues to hold. The second approach consists of including as an additional explanatory variable recent stock returns as suggested by Guay et al. (2005) and Chen et al. (2009a). Accordingly, in Models 2 through 4 we control for price momentum computed as the compound stock returns over the past 3, 6, and 12 months, respectively. In each of these regressions we continue to find that the coefficient on CSR_S is negative and highly statistically significant. Overall, the results in Table 10 help mitigate concerns that noise in analyst forecasts is driving our core findings.

Endogeneity. Similar to related CSR studies, one concern in relation to the analysis is the potential endogeneity and omitted variables bias, which may cloud the interpretation of the causal relation between CSR and the cost of equity capital. For example, although we control for several important factors affecting the cost of equity capital, our evidence on the importance of CSR to equity pricing may be driven by omitted variables that are correlated with both CSR and the cost of equity capital. In particular, prior research suggests that firm-level corporate governance, analyst following, and financial constraints are correlated with both CSR and the cost of equity (Barnea and Rubin, 2006; Brown et al., 2006; Guedhami and Mishra, 2009; Chen et al., 2009a). Thus, omitting these factors from our regressions may lead to a bias of unknown magnitude in the CSR coefficients. Additionally, a firm's choice regarding whether to engage in CSR activities may not be independent of its cost of equity capital, in which case our analysis may be subject to reverse causality concerns. Waddock and Graves (1997) put forward two alternative hypotheses for the direction of causality. According to the good management hypothesis, enhancing CSR performance improves the firm's relationships with key stakeholders, leading to better financial performance (in our case, lower cost of equity). The slack resource hypothesis, in contrast, argues that better financial performance results in resource slack, which allows firms to increase their CSR performance. 
In Table 11, we report the results of various tests that address these concerns. To mitigate the potential omitted variable bias and improve the precision of our estimates, we begin by separately adding to our baseline regression (Table 6, Model 2) various firm-level variables related to corporate governance and financial constraints: the logarithm of one plus the number of institutional investors (Model 1), the fraction of CEO compensation arising from a 1\% increase in the stock price (Model 2), ${ }^{15}$ Bebchuk et al.'s (2009) antitakeover provisions index (Model 3), the logarithm of one plus the number of analysts following the firm (Model 4), and Kaplan and Zingales' (1997) index of financial constraints (Model 5). ${ }^{16}$ We find that these additional controls load with the predicted sign, although the antitakeover provisions index is statistically insignificant. Most important for our purposes, we find that the coefficient on CSR_S is negative and statistically significant at the $1 \%$ level in all of the models.

We also rely on two additional, conventional approaches to ensure the robustness of our results to endogeneity and reverse causality concerns. First, in Model 6 we employ the instrumental variables estimation method. As instruments for CSR_S, we use the industry average CSR score and a dummy variable for whether the previous year's earnings is negative (loss). Second, to mitigate the issue of reverse causality (i.e., the cost of equity in the previous period affects current CSR investment), in Model 7 we follow Chen et al. (2009b) and include the lagged risk premium as an independent variable. This dynamic panel model is estimated using the system GMM technique developed in Blundell and Bond (1998). In both of these models, we find that CSR_S continues to load negatively at the 5\% level or better, reinforcing our previous findings of a negative association between CSR and the cost of equity capital.

${ }^{15}$ Specifically, we calculate the sensitivity of a CEO's stock and option portfolios to a $1 \%$ increase in the underlying stock price, which we label EBC_SENS. Following Bergstresser and Philippon (2006), we then construct the variable $C E O \_I N C$, which reflects the fraction of the CEO's total compensation stemming from a $1 \%$ increase in the firm's stock price: $C E O \_I N C=E B C \_S E N S /\left(E B C \_S E N S+S A L A R Y+B O N U S\right)$. The CEO's stock portfolio comprises restricted and unrestricted stock. The sensitivity of this portfolio is calculated as the market value of the portfolio times 1\%. We follow the methodology proposed by Core and Guay (2002) to estimate option portfolio sensitivity. In particular, we estimate option sensitivities separately for newly granted options, exercisable options, and unexercisable options. We then obtain total option portfolio sensitivity by summing the individual sensitivities. An appendix outlining calculation details is available from the authors upon request.

16 We follow Lamont et al. (2001), who adapt the index to large samples. Specifically, $K Z_{\mathrm{t}}=-1.002\left(C F_{\mathrm{t}} / A_{\mathrm{t}-1}\right)$ $39.368\left(D_{t} / A_{\mathrm{t}-1}\right)-1.315^{*}\left(C_{\mathrm{t}} / A_{\mathrm{t}-1}\right)+3.139^{*} L E V_{\mathrm{t}}+0.283^{*} Q_{\mathrm{t}}$, where $C F$ is cash flow, $D$ denotes cash dividends, $C$ stands for cash holdings, $L E V$ is total debt, $Q$ is Tobin's $Q$, and $A$ denotes total assets. 
Collectively, the results from these tests indicate that endogeneity concerns are not likely to be driving our core evidence. 17

Other Sensitivity Tests. We also perform additional robustness checks, which are unreported for the sake of space. First, in our previous analysis we exclude corporate governance when constructing our CSR metric because we do not consider good corporate governance practices as an indicator of socially responsible behavior. When we recode CSR_S including the corporate governance qualitative area, we find similar results.

Second, prior research suggests that the level of CSR may vary according to industry characteristics (e.g., Waddock and Graves, 1997; McWilliams and Siegel, 2001; Fisman et al., 2005). Therefore, in an attempt to make our proxies for CSR more comparable across industries, we adjust CSR_S for the industry median in each year. The results corroborate our earlier findings, suggesting that industry effects in CSR scores are not driving our results.

Third, a potential issue inherent with the KLD STATS database is that KLD has been adding and eliminating item ratings over time. For instance, reporting on the South Africa strength and concern in the human rights qualitative issue area was stopped in 1995, while the climate change concern in the environment qualitative issue area was added in 1999. As a result, the CSR scores may not be comparable over time. To address this issue, we transform the qualitative issues areas' scores and the overall CSR score into decile ranks computed in each year. A higher value of this variable indicates that the firm's net CSR performance is relatively higher. Corroborating our earlier evidence in Table 6, we find that the CSR decile rank is negatively and significantly (at the $1 \%$ level) associated with the cost of equity capital.

Fourth, there is some evidence that firm-level cost of equity is positively related to industry-level cost of equity (e.g., Gebhardt et al., 2001). We therefore control for the median industry risk premium and find that CSR_S still loads with a negative and significant coefficient.

\footnotetext{
17 In untabulated robustness tests that further rule out endogeneity, we estimate a negative and statistically significant (at the 5\% level) coefficient on CSR_S when (i) we include the initial CSR score recorded when the firm enters the sample, which can be viewed as exogenous with respect to the contemporaneous cost of equity, and (ii) we use the change in the cost of equity as our dependent variable. We thank a reviewer for suggesting these insightful approaches to address endogeneity.
} 
Fifth, we examine the robustness of our results to alternative methodologies to control for cross-sectional and serial dependence including Newey-West, Prais-Winsten, and FamaMacBeth methodologies. In each of these specifications, CSR_S loads negative at the $1 \%$ level.

Sixth, prior research suggests that large and mature firms have greater needs to engage in socially responsible behavior relative to smaller firms (Waddock and Graves, 1997). Similarly, CSR activities may be more important for firms followed by a large number of analysts. Since large firms and firms with high analyst coverage benefit from lower cost of equity capital, our earlier results may simply reflect the dominance in our sample of large U.S. firms with better analyst coverage. Although we control for size in all of our main regressions, we further mitigate this concern by examining the effect of CSR after excluding large firms and firms with high analyst coverage using cutoffs corresponding to the top $1 \%, 5 \%, 10 \%, 25 \%$, and $50 \%$ of firms. All of our core evidence remains unaffected using these smaller subsamples.

Seventh, evidence in Dhaliwal et al. (2009), Hong and Kacperczyk (2009), and Verwijmeren and Derwall (2010) implies that social norms may affect financing decisions (i.e., decisions to issue debt or equity) and in turn the cost of equity financing. In other words, the cost of equity capital could be related to CSR through other economic channels such as leverage. Although all our regressions control for the debt-equity mix $(L E V)$, we repeat our analysis after excluding firms that issue debt or equity in a given year. ${ }^{18}$ The results continue to show a strong negative association between CSR and the cost of equity.

Eighth, our core evidence holds when we re-estimate our main regression after dropping all observations for which the CSR score equals zero, given the possibility that KLD might report zeros for some firms because the staff of KLD have not evaluated them, rather than because the firms have zero performance (Statman and Glushkov, 2009). The results from this robustness test indicate that CSR continues to load negative and significant at the $1 \%$ level (coefficient $=-0.043$ and $t$-statistic $=-3.141)$.

\footnotetext{
${ }_{18}$ We obtain the proceeds from (net) equity and debt issues from the cash flow statement reported in Compustat. When this information is missing, we rely on the indirect balance sheet approach described in Baker and Wurgler (2002). We consider a firm as an equity (debt) issuer if the proceeds from equity (debt) issues in a given year is higher than $1 \%$ of lagged assets.
} 
Finally, we check and find that our results are not sensitive to excluding firms related to tobacco as well as all "sin"-industries, which may have high returns given that they are associated with high litigation risk and positive outcomes from litigation (Hong and Kacperczyk, 2009).

\section{Conclusion}

This paper examines whether corporate social responsibility affects firms' ex ante cost of equity implied in stock prices and analysts' earnings forecasts. We contend that ceteris paribus, high CSR firms should have lower cost of equity capital than low CSR firms owing to low CSR firms having a reduced investor base and higher perceived risk. Using a sample of 12,915 U.S. firm-year observations from 1992 to 2007 and controlling for other firm-specific determinants as well as industry and year fixed effects, we find that firms with higher CSR scores enjoy significantly lower cost of equity capital. The empirical results are consistent with our hypothesis. Furthermore, we find that not all six dimensions of the KLD social performance index are related to the cost of equity. In particular, while CSR investment in employee relations, environmental policies, and product strategies contribute to lowering firms' cost of equity, CSR-related actions in the areas of community relations, diversity, and human rights do not. We also find that, consistent with Hong and Kacperczyk (2009), firms related to the tobacco and nuclear power industries have higher equity financing costs.

In summary, our findings contribute to the debate on whether CSR investments are value-increasing, decreasing, or neutral by showing that improved CSR can enhance firm value by reducing the firm's cost of equity capital. Thus, while prior research emphasizes the importance of corporate governance for firms' valuation and access to external financing, our research suggests that investment in CSR activities is also important to firms as it has power to explain a firm's cost of equity beyond corporate governance and other risk factors. 


\section{Appendix A}

\section{Models of Cost of Equity Capital}

In this appendix, we describe the cost of equity models used in this paper. We start by defining variables and specifying assumptions common to all models. We then successively cover each model and its assumptions.

\section{Common Variables and Assumptions}

$P_{t}=$ stock price in June of year $t$

$D P S_{0}=$ actual dividend per share in year $t-1$

$E P S_{0}=$ actual earnings per share in year $t-1$

$L T G=$ long-term growth forecast in June of year $t$

$F E P S_{t+\tau}=$ forecasted earnings per share for year $t+\tau$ recorded in June of year $t$

$B_{t}=$ book value per share at the beginning of year $t$

$r_{f}=$ yield on a 10-year Treasury note in June of year $t$

As explained in the text, we require firms to have positive one-year-ahead $\left(F E P S_{t+1}\right)$ and two-year-ahead $\left(F E P S_{t+2}\right)$ earnings forecasts as well as a long-term growth forecast $(L T G)$. However, two models call for the use of earnings forecasts beyond year two. If a forecast is not available in I/B/E/S, we impute it from the previous year's forecast and the long-term growth forecast as $F E P S_{t+\tau}=F E P S_{t+\tau-1}(1+L T G)$.

\section{Model 1: Claus and Thomas (2001)}

This model assumes clean surplus accounting (Ohlson, 1995), allowing share price to be expressed in terms of forecasted residual earnings and book values. The explicit forecast horizon is set to five years, beyond which forecasted residual earnings grow at the expected inflation rate, and dividend payout is assumed to be constant at $50 \%$. The valuation equation is given by:

$$
P_{t}=B_{t}+\sum_{\tau=1}^{5} \frac{a e_{t+\tau}}{\left(1+k_{C T}\right)}+\frac{a e_{t+5}(1+g)}{\left(k_{C T}-g\right)\left(1+k_{C T}\right)^{5}}
$$

where:

$$
\begin{aligned}
& a e_{t+\tau}=F E P S_{t+\tau}-k_{C T} B_{t+\tau-1}, \\
& B_{t+\tau}=B_{t+\tau-1}+F E P S_{t+\tau}\left(1-D P R_{t+\tau}\right), \\
& D P R_{t+\tau}=0.5, \text { and } \\
& g=r_{f}-0.03
\end{aligned}
$$


This model also assumes clean surplus accounting, allowing share price to be expressed in terms of forecasted returns on equity $(R O E)$ and book values. The explicit forecast horizon is set to three years, beyond which forecasted $R O E$ decays to the median industry ROE by the twelfth year, and remains constant thereafter. Dividend payout is again assumed to be constant. The valuation equation is given by:

$$
P_{t}=B_{t}+\sum_{\tau=1}^{11} \frac{F R O E_{t+\tau}-k_{G L S}}{\left(1+k_{G L S}\right)} B_{t+\tau-1}+\frac{F R O E_{t+12}-k_{G L S}}{k_{G L S}\left(1+k_{C T}\right)^{11}} B_{t+11}
$$

where:

$F R O E_{t+\tau}=$ forecasted return on equity for year $t+\tau$,

$B_{t+\tau}=B_{t+\tau-1}+F E P S_{t+\tau}\left(1-D P R_{t+\tau}\right)$, and

$D P R_{t+\tau}=$ expected dividend payout ratio in year $t+\tau$.

For the first three years, $F R O E_{t+\tau}$ is set equal to $F E P S_{t+\tau} / B_{t+\tau-1}$. Beyond the third year, $F R O E$ fades linearly to the industry median $R O E$ by the twelfth year. Industries are defined according to the Fama and French (1997) classification and the median industry ROE is calculated over the past ten years excluding loss firms.

The expected dividend payout ratio $D P R_{t+\tau}$ is set equal to $D P S_{0} / E P S_{0}$. If $E P S_{0}$ is negative, it is replaced by the value implied by a $6 \%$ return on assets (the long-run return on assets in the U.S.). We winsorize payout ratios at zero and one.

\section{Model 3: Ohlson and Juettner-Nauroth (2005)}

The model is a generalization of the Gordon constant growth model. It allows share price to be expressed in terms of the one-year-ahead earnings forecast, the near-term and perpetual growth forecasts. The explicit forecast horizon is set to one year, after which forecasted earnings grow at a near-term rate that decays to a perpetual rate. We follow Gode and Mohanram's (2003) implementation of the model. The near-term earnings growth rate is the average of: i) the percentage difference between two-year-ahead and one-year-ahead earnings forecasts, and ii) the I/B/E/S long-term growth forecast. The perpetual growth rate is the expected inflation rate. Dividend per share is assumed to be constant. The model requires positive one-year-ahead and two-year-ahead earnings forecasts. The valuation equation is given by: 


$$
k_{O J}=A+\sqrt{A^{2}+\frac{F E P S_{t+1}}{P_{t}}\left(g_{2}-(\gamma-1)\right)}
$$

where:

$$
\begin{aligned}
& A=\frac{1}{2}\left((\gamma-1)+\frac{D P S_{t+1}}{P_{t}}\right), \\
& D P S_{t+1}=D P S_{0} \\
& g_{2}=\frac{S T G+L T G}{2}, \\
& S T G=\frac{F E P S_{t+2}-F E P S_{t+1}}{F E P S_{t+1}}, \text { and } \\
& (\gamma-1)=r_{f}-0.03 .
\end{aligned}
$$

\section{Model 4: Easton (2004)}

This model is a generalization of the Price-Earnings-Growth (PEG) model and is based on Ohlson and Juettner-Nauroth (2005). It allows share price to be expressed in terms of oneyear-ahead expected dividend per share, plus one-year-ahead and two-year-ahead earnings forecasts. The explicit forecast horizon is set to two years, after which forecasted abnormal earnings grow in perpetuity at a constant rate. The model requires positive one-year-ahead and two-year-ahead earnings forecasts as well as positive change in earnings forecast. The valuation equation is given by:

$$
P_{t}=\frac{F E P S_{t+2}+k_{E S} D P S_{t+1}-F E P S_{t+1}}{k_{E S}{ }^{2}}
$$

where:

$D P S_{t+1}=D P S_{0}$

\section{$\underline{\text { Alternative models }}$}

We also consider alternative models of the cost of equity. These are used in Table 8.

\section{Gordon Finite Horizon model}

This model assumes that dividends grow over an explicit forecasting horizon set to four years, beyond which the firm's return on equity reverts to the expected cost of equity capital. The valuation equation is given by: 


$$
P_{t}=\sum_{\tau=1}^{4} \frac{D P S_{t+\tau}}{\left(1+k_{F H G}\right)}+\frac{N E P S_{t+1}(1+L T G)^{4}}{k_{F H G}\left(1+k_{F H G}\right)^{4}}
$$

where:

$D P S_{t+\tau}=D P S_{0}(1+L T G)^{\tau}$, and

$N E P S_{t+1}=\frac{F E P S_{t+3}}{(1+L T G)^{2}}$.

Price-Earnings-Growth (PEG) ratio

This is a special case of the Easton (2004) model assuming no dividend payments. There are two versions of the model. One is based on short-term earnings forecasts and the other on long-term earnings forecasts. The valuation equations are given by:

$$
\begin{gathered}
P_{t}=\frac{F E P S_{t+2}-F E P S_{t+1}}{k_{P E G 2}{ }^{2}} \text {, and } \\
P_{t}=\frac{F E P S_{t+5}-F E P S_{t+4}}{k_{P E G 5}{ }^{2}} .
\end{gathered}
$$

\section{Earnings-Price $(E P)$ ratio}

This is a special case of the Easton (2004) model assuming that abnormal earnings growth is set to zero. The EP ratio is given by:

$$
E P R=\frac{F E P S_{t+1}}{P_{t}}
$$




\section{Appendix B}

\section{Qualitative Issue Areas and Controversial Business Issues Definitions}

\section{Panel A. Qualitative Issue Areas}

We consider six qualitative issue areas: Community, Diversity, Employee Relations, Environment, Human Rights, and Product Characteristics. Each area has a set of strengths and concerns as illustrated below. We calculate a score for each area equal to the number of strengths minus the number of concerns. We also calculate an overall CSR score equal to the sum of all areas' scores.

\begin{tabular}{|c|c|c|}
\hline & Concerns & Strengths \\
\hline \multirow[t]{8}{*}{ Community } & Investment Controversies & Charitable Giving \\
\hline & Negative Economic Impact & Innovative Giving \\
\hline & Indigenous Peoples Relations & Non-US Charitable Giving \\
\hline & Tax Disputes & Support for Housing \\
\hline & Other Concern & Support for Education \\
\hline & & Indigenous Peoples Relations \\
\hline & & Volunteer Programs \\
\hline & & Other Strength \\
\hline \multirow[t]{8}{*}{ Diversity } & Controversies & CEO \\
\hline & Non-Representation & Promotion \\
\hline & Other Concern & Board of Directors \\
\hline & & Work/Life Benefits \\
\hline & & Women \& Minority Contracting \\
\hline & & Employment of the Disabled \\
\hline & & Gay \& Lesbian Policies \\
\hline & & Other Strength \\
\hline \multirow[t]{7}{*}{ Employee Relations } & Union Relations & Union Relations \\
\hline & Health and Safety Concern & No-Layoff Policy \\
\hline & Workforce Reductions & Cash Profit Sharing \\
\hline & Retirement Benefits Concern & Employee Involvement \\
\hline & Other Concern & Retirement Benefits Strength \\
\hline & & Health and Safety Strength \\
\hline & & Other Strength \\
\hline \multirow[t]{7}{*}{ Environment } & Hazardous Waste & Beneficial Products and Services \\
\hline & Regulatory Problems & Pollution Prevention \\
\hline & Ozone Depleting Chemicals & Recycling \\
\hline & Substantial Emissions & Clean Energy \\
\hline & Agricultural Chemicals & Communications \\
\hline & Climate Change & Property, Plant, and Equipment \\
\hline & Other Concern & Other Strength \\
\hline \multirow[t]{8}{*}{ Human rights } & South Africa & Positive Record in South Africa \\
\hline & Northern Ireland & Indigenous Peoples Relations Strength \\
\hline & Burma Concern & Labor Rights Strength \\
\hline & Mexico & Other Strength \\
\hline & Labor Rights Concern & \\
\hline & Indigenous Peoples Relations & \\
\hline & Concern & \\
\hline & Other Concern & \\
\hline \multirow[t]{4}{*}{ Product characteristics } & Product Safety & Quality \\
\hline & Marketing/Contracting Concern & R\&D/Innovation \\
\hline & Antitrust & Benefits to Economically Disadvantaged \\
\hline & Other Concern & Other Strength \\
\hline
\end{tabular}




\begin{tabular}{|c|c|}
\hline \\
\hline \multicolumn{2}{|c|}{$\begin{array}{l}\text { Panel B. Controversial Business Issues } \\
\text { We consider six controversial business issues: Alcohol, Gambling, Tobacco, Firearms, Military, and Nuclear Power. } \\
\text { Each issue has a set of concerns. We construct a dummy variable for each controversial business issue that equals } 1 \text { if } \\
\text { the firm is involved in at least one concern, and } 0 \text { otherwise. We also construct a dummy variable that equals } 1 \text { if the } \\
\text { firm is involved in any controversial business issue, and } 0 \text { otherwise. }\end{array}$} \\
\hline & Concerns \\
\hline Alcohol & $\begin{array}{l}\text { Licensing } \\
\text { Manufacturers } \\
\text { Manufacturers of products necessary for production of alcoholic beverages } \\
\text { Retailers } \\
\text { Ownership by an alcohol company } \\
\text { Ownership of an alcohol company } \\
\text { Alcohol other concern }\end{array}$ \\
\hline Gambling & $\begin{array}{l}\text { Licensing } \\
\text { Manufacturers } \\
\text { Owners and operators } \\
\text { Supporting products or services } \\
\text { Ownership by a gambling company } \\
\text { Ownership of a gambling company } \\
\text { Gambling other concern }\end{array}$ \\
\hline Tobacco & $\begin{array}{l}\text { Licensing } \\
\text { Manufacturers } \\
\text { Manufacturers of products necessary for production of tobacco products } \\
\text { Retailers } \\
\text { Ownership by a tobacco company } \\
\text { Ownership of a tobacco company } \\
\text { Tobacco other concern }\end{array}$ \\
\hline Firearms & $\begin{array}{l}\text { Manufacturers } \\
\text { Retailers } \\
\text { Ownership by a firearms company } \\
\text { Ownership of a firearms company }\end{array}$ \\
\hline Military & $\begin{array}{l}\text { Manufacturers of weapons or weapons systems } \\
\text { Manufacturers of components for weapons or weapons systems } \\
\text { Ownership by a military company } \\
\text { Ownership of a military company } \\
\text { Minor weapons contracting involvement } \\
\text { Major weapons-related supplier } \\
\text { Military other concern }\end{array}$ \\
\hline Nuclear Power & $\begin{array}{l}\text { Construction \& design of nuclear power plants } \\
\text { Nuclear power fuel and key parts } \\
\text { Nuclear power service provider } \\
\text { Ownership of nuclear power plants } \\
\text { Ownership by a nuclear power company } \\
\text { Ownership of a nuclear power company } \\
\text { Design } \\
\text { Fuel cycle/key parts } \\
\text { Nuclear power other concern }\end{array}$ \\
\hline
\end{tabular}




\section{Appendix C}

Variable Definitions and Data Sources

\begin{tabular}{|c|c|c|}
\hline Variable & Definition & Source \\
\hline \multicolumn{3}{|c|}{ Panel A. Dependent variables } \\
\hline$r_{C T}$ & $\begin{array}{l}\text { Implied cost of equity premium defined as the cost of equity } \\
\text { derived from the Claus and Thomas (2001) model estimated in June } \\
\text { of each year minus the rate on a 10-year Treasury bond. }\end{array}$ & $\begin{array}{l}\text { Authors' calculations based on } \\
\text { I/B/E/S and Compustat data }\end{array}$ \\
\hline$r_{G L S}$ & $\begin{array}{l}\text { Implied cost of equity premium defined as the cost of equity } \\
\text { derived from the Gebhardt, Lee, and Swaminathan }(2001) \text { model } \\
\text { estimated in June of each year minus the rate on a 10-year Treasury } \\
\text { bond. }\end{array}$ & As above \\
\hline$r_{O J}$ & $\begin{array}{l}\text { Implied equity premium defined as the cost of equity derived from } \\
\text { the Ohlson and Juttner-Nauroth (2005) model estimated in June of } \\
\text { each year minus the rate on a 10-year Treasury bond. }\end{array}$ & As above \\
\hline$r_{E S}$ & $\begin{array}{l}\text { Implied cost of equity premium defined as the cost of equity } \\
\text { derived from the Easton (2004) model estimated in June of each year } \\
\text { minus the rate on a 10-year Treasury bond. }\end{array}$ & As above \\
\hline$r_{A V G}$ & Average of $r_{G L S}, r_{C T}, r_{O J}$, and $r_{E S}$ & As above \\
\hline \multicolumn{3}{|c|}{ Panel B. Corporate social responsibility variables } \\
\hline CSR_COM_S & $\begin{array}{l}\text { The Community score equals the number of strengths minus the } \\
\text { number of concerns in the Community qualitative issues area. }\end{array}$ & $\begin{array}{l}\text { Authors' calculations based on } \\
\text { KLD STATS data }\end{array}$ \\
\hline CSR_DIV_S & $\begin{array}{l}\text { The Diversity score equals the number of strengths minus the } \\
\text { number of concerns in the Diversity qualitative issues area. }\end{array}$ & As above \\
\hline CSR_EMP_S & $\begin{array}{l}\text { The Employee Relations score equals to the number of strengths } \\
\text { minus the number of concerns in the Employee Relations qualitative } \\
\text { issues area. }\end{array}$ & As above \\
\hline CSR_ENV_S & $\begin{array}{l}\text { The Environment score equals the number of strengths minus the } \\
\text { number of concerns in the Environment qualitative issues area. }\end{array}$ & As above \\
\hline CSR_HUM_S & $\begin{array}{l}\text { The Human Rights score equals the number of strengths minus the } \\
\text { number of concerns in the Human Rights qualitative issues area. }\end{array}$ & As above \\
\hline CSR_PRO_S & $\begin{array}{l}\text { The Product score equals the number of strengths minus the number } \\
\text { of concerns in the Product qualitative issues area. }\end{array}$ & As above \\
\hline CSR_S & $\begin{array}{l}\text { The CSR score equals the sum of the Community, Diversity, } \\
\text { Employee, Environment, Human Rights, and Product } \\
\text { Characteristics qualitative issues areas scores. }\end{array}$ & As above \\
\hline CSR_CONTR & $\begin{array}{l}\text { Dummy variable set to } 1 \text { if the firm is involved in a controversial } \\
\text { business issue, and } 0 \text { otherwise. }\end{array}$ & As above \\
\hline CSR_ALC & $\begin{array}{l}\text { Dummy variable set to } 1 \text { if the firm is involved in the Alcohol } \\
\text { controversial business issue, and } 0 \text { otherwise. }\end{array}$ & As above \\
\hline CSR_GAM & $\begin{array}{l}\text { Dummy variable set to } 1 \text { if the firm is involved in the Gambling } \\
\text { controversial business issue, and } 0 \text { otherwise. }\end{array}$ & As above \\
\hline CSR_TOB & $\begin{array}{l}\text { Dummy variable set to } 1 \text { if the firm is involved in the Tobacco } \\
\text { controversial business issue, and } 0 \text { otherwise. }\end{array}$ & As above \\
\hline CSR_FIR & $\begin{array}{l}\text { Dummy variable set to } 1 \text { if the firm is involved in the Firearms } \\
\text { controversial business issue, and } 0 \text { otherwise. }\end{array}$ & As above \\
\hline CSR_MIL & $\begin{array}{l}\text { Dummy variable set to } 1 \text { if the firm is involved in the Military } \\
\text { controversial business issue, and } 0 \text { otherwise. }\end{array}$ & As above \\
\hline CSR_NUC & $\begin{array}{l}\text { Dummy variable set to } 1 \text { if the firm is involved in the Nuclear } \\
\text { controversial business issue, and } 0 \text { otherwise. }\end{array}$ & As above \\
\hline
\end{tabular}




\begin{tabular}{|c|c|c|}
\hline \multicolumn{3}{|c|}{ Panel C. Control variables } \\
\hline BETA & $\begin{array}{l}\text { Market beta obtained from regressions of a firm's monthly excess } \\
\text { stock returns on the corresponding CRSP value-weighted index } \\
\text { excess returns using at least } 24 \text { months and up to } 60 \text { months ending } \\
\text { in June of each year. Excess returns are monthly returns minus the } \\
\text { one-month Treasury bill rate. }\end{array}$ & $\begin{array}{l}\text { Authors' calculations based on } \\
\text { CRSP data }\end{array}$ \\
\hline SIZE & Natural logarithm of total assets in $\$$ Million. & $\begin{array}{l}\text { Authors' calculations based on } \\
\text { Compustat data }\end{array}$ \\
\hline BTM & $\begin{array}{l}\text { Book value to market value of equity. Book value is defined as the } \\
\text { book value of shareholders' equity plus deferred taxes and } \\
\text { investment tax credits (if available) minus the book value of } \\
\text { preferred stock. Depending on data availability, the book value of } \\
\text { preferred stock is defined, in the following order, as the } \\
\text { redemption, liquidation, or par value. }\end{array}$ & As above \\
\hline$L E V$ & $\begin{array}{l}\text { Leverage ratio defined as the ratio of total debt to the market value } \\
\text { of equity. }\end{array}$ & As above \\
\hline LTG & Average long-term growth forecast reported in June of year $t$. & $\mathrm{I} / \mathrm{B} / \mathrm{E} / \mathrm{S}$ \\
\hline DISP & $\begin{array}{l}\text { Dispersion of analyst forecasts defined as the coefficient of variation } \\
\text { of one-year-ahead analyst forecasts of earnings per share in June of } \\
\text { year } t \text {. }\end{array}$ & $\begin{array}{l}\text { Authors' calculations based on } \\
\text { I/B/E/S data }\end{array}$ \\
\hline FBIAS & $\begin{array}{l}\text { Forecast optimism bias defined as the difference between the one- } \\
\text { year-ahead consensus earnings forecast and realized earnings } \\
\text { deflated by June-end stock price. }\end{array}$ & As above \\
\hline MOM3 & Compound stock returns over the past 3 months. & $\begin{array}{l}\text { Authors' calculations based on } \\
\text { CRSP data }\end{array}$ \\
\hline MOM6 & Compound stock returns over the past 6 months. & As above \\
\hline MOM12 & Compound stock returns over the past 12 months. & As above \\
\hline INST & Logarithm of one plus the number of institutional investors. & $\begin{array}{l}\text { Authors' calculations based on } \\
\text { Thomson 13-F data }\end{array}$ \\
\hline CEO_INC & $\begin{array}{l}\text { Fraction of the CEO's total compensation arising from a } 1 \% \text { increase } \\
\text { in the firm's stock price. }\end{array}$ & $\begin{array}{l}\text { Authors' calculations based on } \\
\text { Execucomp data }\end{array}$ \\
\hline$E I$ & $\begin{array}{l}\text { Bebchuk, Cohen, and Ferrell (2005) index of six antitakeover } \\
\text { provisions. }\end{array}$ & $\begin{array}{l}\text { Authors' calculations based on } \\
\text { RiskMetrics data }\end{array}$ \\
\hline ANA & Logarithm of 1 plus the number of analysts following the firm. & $\begin{array}{l}\text { Authors' calculations based on } \\
\text { I/B/E/S data }\end{array}$ \\
\hline KZ & $\begin{array}{l}\text { Kaplan and Zingales' (1997) index of financial constraints as } \\
\text { implemented by Lamont et al. (2001). }\end{array}$ & $\begin{array}{l}\text { Authors' calculations based on } \\
\text { Compustat data }\end{array}$ \\
\hline
\end{tabular}




\section{References}

Ali, A., A. Klein, and J. Rosenfeld, 1992, Analysts' Use of Information about Permanent and Transitory Earnings Components in Forecasting Annual EPS, The Accounting Review 67, 183-198.

Attig, N., O. Guedhami, and D. Mishra, 2008, Multiple Large Shareholders, Control Contests, and Implied Cost of Equity, Journal of Corporate Finance 14, 721-737.

Baker, M. and J. Wurgler, 2002, Market Timing and Capital Structure, Journal of Finance 57, 1-32.

Barnea, A. and A. Rubin, 2006, Corporate Social Responsibility as a Conflict between Shareholders, Working Paper, Simon Fraser University.

Bassen, A., H.-M. Hölz, and J. Schlange, 2006, The Influence of Corporate Responsibility on the Cost of Capital: An Empirical Analysis, Hamburg: Schlange \& Co, Universität Hamburg, Deutsche Bank.

Bebchuk, L., A. Cohen and A. Ferrell, 2009, What Matters in Corporate Governance?, Review of Financial Studies 22, 783-827.

Bergstresser, D. and T. Philippon, 2006, CEO Incentives and Earnings Management, Journal of Financial Economics 80, 511-529.

Blundell, R. and S. Bond, 1998, Initial Conditions and Moment Restrictions in Dynamic Panel Data Models, Journal of Econometrics 87, 115-143.

Boubakri, N., O. Guedhami and D. Mishra, 2010, Family Control and the Implied Cost of Equity: Evidence Before and After the Asian Financial Crisis, Journal of International Business Studies 41, 451-474.

Bowen, R., X. Chen, and Q. Cheng, 2008, Analyst Coverage and the Cost of Raising Equity Capital: Evidence from Underpricing of Seasoned Equity Offerings, Contemporary Accounting Research 25, 657-699.

Brammer, S., C. Brooks, and S. Pavelin, 2006, Corporate Social Performance and Stock Returns: UK Evidence from Disaggregate Measures, Financial Management 35, 97-116.

Brown, W., E. Helland and J. Smith, 2006, Corporate Philanthropic Practices, Journal of Corporate Finance 12, 855-877.

Chen, K., Z. Chen, and K. Wei, 2009a, Legal Protection of Investors, Corporate Governance, and the Cost of Equity Capital. Journal of Corporate Finance 15, 273-289.

Chen, K., Z. Chen, and K. Wei, 2009b, Agency Costs of Free Cash Flow and the Effect of Shareholder Rights on the Implied Cost of Equity Capital, Journal of Financial and Quantitative Analysis, forthcoming.

Claus, J. and J. Thomas, 2001, Equity Premia as Low as Three Percent? Evidence from Analysts' Earnings Forecasts for Domestic and International Stock Markets, Journal of Finance 56, $1629-1666$.

Core, J. and W. Guay, 2002, Estimating the Value of Employee Stock Option Portfolios and Their Sensitivities to Price and Volatility, Journal of Accounting Research 40, 613-630.

Dhaliwal, D., S. Eheitzman, and O. Z. Li, 2006, Taxes, Leverage, and the Cost of Equity Capital, Journal of Accounting Research 44, 691-723. 
Dhaliwal, D., O. Z. Li, A. H. Tsang, and Y. G. Yang, 2009, Voluntary Non-Financial Disclosure and the Cost of Equity Capital: The Case of Corporate Social Responsibility Reporting, Working Paper, University of Arizona.

Easton, P. D., 2004, PE Ratios, PEG Ratios, and Estimating the Implied Expected Rate of Return on Equity Capital, The Accounting Review 79, 73-95.

Easton, P. D. and G. A. Sommers, 2007, Effect of Analysts' Optimism on Estimates of the Expected Rate of Return Implied by Earnings Forecasts, Journal of Accounting Research 45, 983-1015.

El Ghoul, S., O. Guedhami, and J. Pittman, 2010, The Role of IRS Monitoring in Equity Pricing in Public Firms, Contemporary Accounting Research, forthcoming.

Elton, E., 1999, Expected Return, Realized Return, and Asset Pricing Tests, Journal of Finance 54, $1199-1220$.

Fama, E. F. and K. R. French, 1992, The Cross Section of Expected Stock Returns, Journal of Finance 47, 427-466.

Fama, E. F and K. R. French, 1993, Common Risk Factors in the Returns on Stocks and Bonds, Journal of Financial Economics 33, 3-56.

Fama, E. F. and K. R. French, 1997, Industry Costs of Equity, Journal of Financial Economics 43, 153-194.

Feldman, S. J., P. A. Soyka, and P. Ameer, 1997, Does Improving a Firm's Environmental Management System and Environmental Performance Result in a Higher Stock Price?, Journal of Investing 6, 87-97.

Fisman, R., G. Heal, and V. B. Nair, 2005, A Model of Corporate Philanthropy, Working Paper, Columbia University.

Fombrun, C. and M. Shanely, 1990, What's in a Name? Reputation Building and Corporate Strategy, Academy of Management Journal 33, 233-258.

Francis, J., R. Lafond, P. M. Olsson, and K. Schipper, 2005, The Market Pricing of Accruals Quality, Journal of Accounting and Economics 39, 295-327.

Frederick, W.C., 1995, Values, Nature and Culture in the American Corporation, Oxford University Press, New York.

Galema R., A. Plantinga and B. Scholtens, 2008, The Stocks at Stake: Return and Risk in Socially Responsible Investment, Journal of Banking and Finance 32, 2646-2654.

Gebhardt, W., C. Lee, and B. Swaminathan, 2001, Towards an Implied Cost of Capital, Journal of Accounting Research 39, 135-176.

Gode, D. and P. Mohanram, 2003, Inferring the Cost of Capital Using the Ohlson-Juettner Model, Review of Accounting Studies 8, 399-431.

Gordon, J. and M. Gordon, 1997, The Finite Horizon Expected Return Model, Financial Analysts Journal 53, 52-61.

Guay, W., S.P. Kothari, and S. Shu, 2005, Properties of Implied Cost of Capital Using Analysts' Forecasts, Working Paper, University of Pennsylvania. 
Guedhami, O. and D. Mishra, 2009, Excess Control, Corporate Governance, and Implied Cost of Equity: International Evidence, Financial Review 44,489-524.

Hail, L. and C. Leuz, 2006, International Differences in Cost of Equity Capital: Do Legal Institutions and Securities Regulations Matter?, Journal of Accounting Research 44, 485531.

Hail, L. and C. Leuz, 2009, Cost of Capital Effects and Changes in Growth Expectations around U.S. Cross-Listings, Journal of Financial Economics 93, 428-454.

Hamilton, S., H. Jo and M. Statman, 1993, Doing Well While Doing Good? The Investment Performance of Socially Responsible Mutual Funds, Financial Analysis Journal 49, 62-97.

Harjoto, M. and H. Jo, 2007, Corporate Governance and Firm Value: The Impact of Corporate Social Responsibility, Working Paper, Santa Clara University.

Heinkel, R., A. Kraus and J. Zechner, 2001, The Effect of Green Investment on Corporate Behavior, Journal of Financial and Quantitative Analysis 36, 431-449.

Hill, R., T. Ainscough, T. Shank, and D. Manullang, 2007, Corporate Social Responsibility and Socially Responsible Investing: A Global Perspective, Journal of Business Ethics 70, 165174.

Hong, H. and M. Kacperczyk, 2009, The Price of Sin: The Effects of Social Norms on Markets, Journal of Financial Economics 93, 15-36.

Hribar, P. and N. Jenkins, 2004, The Effect of Accounting Restatements on Earnings Revisions and the Estimated Cost of Capital, Review of Accounting Studies 9, 337-356.

Kaplan, S. N., and L. Zingales, 1997, Do Investment-Cash Flow Sensitivities Provide Useful Measures of Financing Constraints?, Quarterly Journal of Economics 112, 169-215.

Kempf, A. and P. Osthoff, 2007, The Effect of Socially Responsible Investing on Financial Performance, European Financial Management 13, 908-922.

King, A., 1995, Avoiding Ecological Surprise: Lessons from Long Standing Communities, Academy of Management Review 20, 961-985.

Kothari, S. P. 2001, Capital Markets Research in Accounting, Journal of Accounting and Economics $31,105-231$.

Lamont, O., C. Polk, and J. Saa-Requejo, 2001, Financial Constraints and Stock Returns, Review of Financial Studies 14, 529-554.

Lintner, J., 1965, The Valuation of Risk Assets and the Selection of Risky Investments in Stock Portfolios and Capital Budgets, Review of Economics and Statistics 47, 13-37.

McGuire, J., A. Sundgren, and T. Schneeweis, 1988, Corporate Social Responsibility and Firm Financial Performance. Academy of Management Journal 31, 854-872.

McWilliams, A. and D. Siegel, 2001, Corporate Social Responsibility: A Theory of the Firm Perspective, Academy of Management Review 28, 117-127.

Merton, R.C., 1987, A Simple Model of Capital Market Equilibrium with Incomplete Information, Journal of Finance 42, 483-510.

Modigliani, F. and M. Miller, 1958, The Cost of Capital, Corporation Finance and the Theory of Investment, American Economic Review 48, 261-297. 
Nelling, E. and E. Webb, 2009, Corporate Social Responsibility and Financial Performance: The 'Virtuous Circle' Revisited, Review of Quantitative Finance and Accounting 32, 197-209.

Ohlson, J. and B. Juettner-Nauroth, 2005, Expected EPS and EPS Growth as Determinants of Value, Review of Accounting Studies 10, 349-65.

Ohlson, J., 1995, Earnings, Book Value, and Dividends in Security Valuation, Contemporary Accounting Research 11, 661-687.

Pástor, L., M. Sinha, and B. Swaminathan, 2008, Estimating the Intertemporal Risk-Return Tradeoff Using the Implied Cost of Capital, Journal of Finance 63: 2859-2897.

Renneboog, L., J. Horst, and C. Zhang, 2008, Socially Responsible Investments: Institutional Aspects, Performance, and Investor Behavior, Journal of Banking and Finance 32, 17231742.

Roberts, P. and G. Dowling. 2002, Corporate Reputation and Sustained Superior Financial Performance, Strategic Management Journal 23, 1077-1093.

Robinson, M., A. Kleffner, and S. Bertels, 2008, The Value of a Reputation for Corporate Social Responsibility: Empirical Evidence, Working Paper, University of Michigan.

Sharpe, W., 1964, Capital Asset Prices: A Theory of Market Equilibrium under Conditions of Risk, Journal of Finance 19, 425-442.

Spicer, B. H., 1978, Investors, Corporate Social Performance and Information Disclosure: An Empirical Study, The Accounting Review 53, 94-111.

Starks, L. T., 2009, EFA Keynote Speech: "Corporate Governance and Corporate Social Responsibility: What Do Investors Care about? What Should Investors Care about?", Financial Review 44, 461-468.

Statman, M. and D. Glushkov, 2009, The Wages of Social Responsibility, Financial Analysts Journal 65, 33-46.

Verwijmeren, P. and J. Derwall, 2010, Employee Well-being, Firm Leverage, and Bankruptcy Risk, Journal of Banking and Finance 34, 956-964.

Waddock, S. and S. Graves, 1997, The Corporate Social Performance-Financial Performance Link, Strategic Management Journal 18, 303-319. 
Table 1

Sample Breakdown by Industry and Year

\begin{tabular}{|c|c|c|c|c|c|}
\hline Industry & $\mathbf{N}$ & $\%$ & Industry & $\mathbf{N}$ & $\%$ \\
\hline Agriculture & 25 & 0.19 & Measuring \& Control Equipment & 238 & 1.84 \\
\hline Food Products & 269 & 2.08 & Business Supplies & 279 & 2.16 \\
\hline Candy \& Soda & 24 & 0.19 & Shipping Containers & 62 & 0.48 \\
\hline Beer \& Liquor & 76 & 0.59 & Transportation & 303 & 2.35 \\
\hline Tobacco Products & 25 & 0.19 & Wholesale & 348 & 2.69 \\
\hline Recreation & 65 & 0.50 & Retail & 896 & 6.94 \\
\hline Entertainment & 116 & 0.90 & Restaurants, Hotels \& Motels & 218 & 1.69 \\
\hline Printing \& Publishing & 249 & 1.93 & Banking & 1,299 & 10.06 \\
\hline Consumer Goods & 279 & 2.16 & Insurance & 603 & 4.67 \\
\hline Apparel & 223 & 1.73 & Real Estate & 14 & 0.11 \\
\hline Healthcare & 173 & 1.34 & Trading & 400 & 3.10 \\
\hline Medical Equipment & 335 & 2.59 & Almost Nothing & 64 & 0.50 \\
\hline Pharmaceutical Products & 460 & 3.56 & Total & 12,915 & 100 \\
\hline Chemicals & 344 & 2.66 & & & \\
\hline Rubber \& Plastic Products & 63 & 0.49 & Year & $\mathbf{N}$ & $\%$ \\
\hline Textiles & 53 & 0.41 & 1992 & 343 & 2.66 \\
\hline Construction Materials & 230 & 1.78 & 1993 & 351 & 2.72 \\
\hline Construction & 129 & 1.00 & 1994 & 359 & 2.78 \\
\hline Steel Works Etc & 126 & 0.98 & 1995 & 386 & 2.99 \\
\hline Fabricated Products & 10 & 0.08 & 1996 & 415 & 3.21 \\
\hline Machinery & 493 & 3.82 & 1997 & 426 & 3.30 \\
\hline Electrical Equipment & 171 & 1.32 & 1998 & 440 & 3.41 \\
\hline Automobiles \& Trucks & 223 & 1.73 & 1999 & 448 & 3.47 \\
\hline Aircraft & 98 & 0.76 & 2000 & 468 & 3.62 \\
\hline Shipbuilding \& Railroad Equipment & 56 & 0.43 & 2001 & 446 & 3.45 \\
\hline Defense & 21 & 0.16 & 2002 & 747 & 5.78 \\
\hline Precious Metals & 17 & 0.13 & 2003 & 797 & 6.17 \\
\hline Non-Metallic \& Industrial Metal Mining & 28 & 0.22 & 2004 & 1,841 & 14.25 \\
\hline Coal & 27 & 0.21 & 2005 & 1,835 & 14.21 \\
\hline Petroleum \& Natural Gas & 382 & 2.96 & 2006 & 1,807 & 13.99 \\
\hline Utilities & 676 & 5.23 & 2007 & 1,806 & 13.98 \\
\hline Communication & 286 & 2.21 & Total & 12,915 & 100 \\
\hline Personal Services & 149 & 1.15 & & & \\
\hline Business Services & 1,113 & 8.62 & & & \\
\hline Computers & 455 & 3.52 & & & \\
\hline Electronic Equipment & 722 & 5.59 & & & \\
\hline
\end{tabular}

This table presents the industry (according to the 48 industry group affiliations in Fama and French, 1997) and calendar year distributions for the 12,915 firm-year observations comprising the sample between 1992 and 2007. 
Table 2

Descriptive Statistics and Correlation Coefficients for Implied Equity Premium Estimates

\begin{tabular}{|c|c|c|c|c|c|}
\hline \multicolumn{6}{|c|}{ Panel A. Descriptive Statistics for Implied Equity Premium Estimates } \\
\hline Variable & Mean & Q1 & Median & Q3 & St. Dev. \\
\hline$r_{C T}$ & 3.92 & 2.51 & 3.62 & 4.94 & 2.62 \\
\hline$r_{G L S}$ & 3.76 & 2.29 & 3.70 & 5.09 & 3.18 \\
\hline$r_{O J}$ & 5.61 & 4.04 & 5.14 & 6.55 & 2.79 \\
\hline$r_{E S}$ & 5.71 & 3.50 & 4.92 & 7.00 & 3.78 \\
\hline$r_{A V G}$ & 4.75 & 3.28 & 4.39 & 5.76 & 2.40 \\
\hline 1992 & 4.44 & 2.70 & 4.00 & 5.56 & 2.49 \\
\hline 1993 & 4.80 & 3.32 & 4.39 & 5.69 & 2.29 \\
\hline 1994 & 3.88 & 2.52 & 3.46 & 4.66 & 2.25 \\
\hline 1995 & 4.64 & 3.17 & 4.16 & 5.49 & 2.18 \\
\hline 1996 & 3.51 & 2.16 & 3.05 & 4.44 & 2.12 \\
\hline 1997 & 3.29 & 2.16 & 3.03 & 4.07 & 1.71 \\
\hline 1998 & 3.86 & 2.64 & 3.62 & 4.71 & 1.92 \\
\hline 1999 & 3.48 & 1.87 & 3.17 & 4.49 & 2.24 \\
\hline 2000 & 4.75 & 2.52 & 4.33 & 6.20 & 3.45 \\
\hline 2001 & 4.62 & 2.78 & 4.28 & 5.56 & 2.83 \\
\hline 2002 & 5.07 & 3.52 & 4.71 & 6.00 & 2.41 \\
\hline 2003 & 6.07 & 4.58 & 5.75 & 7.00 & 2.36 \\
\hline 2004 & 4.95 & 3.61 & 4.58 & 5.94 & 2.11 \\
\hline 2005 & 5.40 & 4.12 & 5.05 & 6.30 & 2.11 \\
\hline 2006 & 4.93 & 3.56 & 4.46 & 5.68 & 2.45 \\
\hline 2007 & 4.44 & 3.13 & 4.09 & 5.17 & 2.27 \\
\hline
\end{tabular}

Panel B. Pearson Correlation Coefficients between Implied Equity Premium Estimates

\begin{tabular}{lcccc}
\hline & $r_{C T}$ & $r_{G L S}$ & $r_{O J}$ & $r_{E S}$ \\
\hline$r_{G L S}$ & 0.415 & & & \\
$r_{O J}$ & 0.453 & 0.318 & & \\
$r_{E S}$ & 0.367 & 0.319 & 0.908 & \\
$r_{A V G}$ & 0.686 & 0.662 & 0.877 & 0.863 \\
\hline
\end{tabular}

This table presents the cost of equity premium estimates' distribution statistics and correlation coefficients for the 12,915 firm-year sample observations between 1992 and 2007. Panel A provides the mean, first quartile, median, third quartile, and standard deviation. Panel B shows Pearson pair-wise correlations. $r_{A V G}$ is the average implied cost of equity premium obtained from four models developed by Claus and Thomas (2001), Gebhardt, Lee, and Swaminathan (2001), Ohlson and Juettner-Nauroth (2005), and Easton (2004), which we denote $r_{C T}, r_{G L S}, r_{O I}$, and $r_{E S \text {, }}$ respectively. Appendix A provides details on the implementation of the four models. All correlation coefficients are significant at the $1 \%$ level. 
Table 3

Descriptive Statistics for Corporate Social Responsibility Data

\begin{tabular}{|c|c|c|c|c|c|c|c|}
\hline \multicolumn{8}{|c|}{ Panel A. Descriptive Statistics for the Corporate Social Responsibility Score } \\
\hline & Mean & Min & Q1 & Median & Q3 & Max & St. Dev. \\
\hline 1992 & 0.39 & -7 & -1 & 0 & 2 & 5 & 1.99 \\
\hline 1993 & 0.44 & -7 & -1 & 1 & 2 & 7 & 2.22 \\
\hline 1994 & 0.35 & -7 & -1 & 0 & 2 & 7 & 2.43 \\
\hline 1995 & 0.46 & -7 & -1 & 0 & 2 & 8 & 2.54 \\
\hline 1996 & 0.86 & -7 & -1 & 1 & 2 & 11 & 2.55 \\
\hline 1997 & 0.93 & -8 & -1 & 1 & 2 & 9 & 2.34 \\
\hline 1998 & 0.98 & -6 & 0 & 1 & 3 & 10 & 2.5 \\
\hline 1999 & 0.96 & -7 & 0 & 1 & 3 & 9 & 2.51 \\
\hline 2000 & 0.97 & -7 & -1 & 1 & 3 & 11 & 2.57 \\
\hline 2001 & 0.94 & -6 & -1 & 1 & 2 & 11 & 2.56 \\
\hline 2002 & 0.42 & -9 & -1 & 0 & 2 & 9 & 2.27 \\
\hline 2003 & 0.33 & -9 & -1 & 0 & 1 & 9 & 2.25 \\
\hline 2004 & -0.08 & -9 & -1 & 0 & 1 & 10 & 1.76 \\
\hline 2005 & -0.25 & -8 & -1 & 0 & 1 & 11 & 1.92 \\
\hline 2006 & -0.17 & -8 & -1 & 0 & 1 & 11 & 2.06 \\
\hline 2007 & -0.17 & -8 & -1 & 0 & 1 & 15 & 2.23 \\
\hline All years & 0.19 & -9 & -1 & 0 & 1 & 15 & 2.22 \\
\hline \multicolumn{8}{|c|}{ Panel B. Frequency Distribution for Controversial Business Areas } \\
\hline Year & CSR_CONTR & CSR_ALC & CSR_GAM & CSR_TOB & CSR_FIR & CSR_MIL & CSR_NUC \\
\hline 1992 & $12.54 \%$ & $0.58 \%$ & $0.29 \%$ & $0.29 \%$ & . & $9.91 \%$ & $2.04 \%$ \\
\hline 1993 & $11.68 \%$ & $0.85 \%$ & $0.28 \%$ & $0.28 \%$ & . & $8.83 \%$ & $1.71 \%$ \\
\hline 1994 & $12.81 \%$ & $0.84 \%$ & $0.28 \%$ & $0.56 \%$ & . & $9.75 \%$ & $1.67 \%$ \\
\hline 1995 & $11.14 \%$ & $0.78 \%$ & $1.04 \%$ & $0.52 \%$ & . & $8.03 \%$ & $1.55 \%$ \\
\hline 1996 & $11.81 \%$ & $0.72 \%$ & $1.20 \%$ & $0.72 \%$ & . & $8.19 \%$ & $1.93 \%$ \\
\hline 1997 & $11.97 \%$ & $0.94 \%$ & $1.41 \%$ & $0.70 \%$ & . & $7.04 \%$ & $2.58 \%$ \\
\hline 1998 & $10.91 \%$ & $1.14 \%$ & $1.14 \%$ & $0.68 \%$ & . & $6.14 \%$ & $2.50 \%$ \\
\hline 1999 & $10.49 \%$ & $1.12 \%$ & $0.89 \%$ & $0.45 \%$ & $0.00 \%$ & $4.91 \%$ & $3.57 \%$ \\
\hline 2000 & $10.68 \%$ & $1.07 \%$ & $0.85 \%$ & $0.64 \%$ & $0.00 \%$ & $4.27 \%$ & $4.06 \%$ \\
\hline 2001 & $12.33 \%$ & $1.12 \%$ & $1.35 \%$ & $0.67 \%$ & $0.00 \%$ & $4.93 \%$ & $4.48 \%$ \\
\hline 2002 & $9.64 \%$ & $0.94 \%$ & $1.20 \%$ & $0.67 \%$ & $0.27 \%$ & $3.35 \%$ & $3.48 \%$ \\
\hline 2003 & $8.91 \%$ & $0.88 \%$ & $1.25 \%$ & $0.50 \%$ & $0.25 \%$ & $3.51 \%$ & $2.89 \%$ \\
\hline 2004 & $7.93 \%$ & $0.65 \%$ & $1.36 \%$ & $0.60 \%$ & $0.22 \%$ & $4.13 \%$ & $1.41 \%$ \\
\hline 2005 & $8.07 \%$ & $0.71 \%$ & $1.53 \%$ & $0.65 \%$ & $0.27 \%$ & $4.03 \%$ & $1.36 \%$ \\
\hline 2006 & $8.36 \%$ & $0.94 \%$ & $1.60 \%$ & $0.44 \%$ & $0.17 \%$ & $3.87 \%$ & $1.83 \%$ \\
\hline 2007 & $7.86 \%$ & $1.11 \%$ & $1.33 \%$ & $0.39 \%$ & $0.17 \%$ & $3.54 \%$ & $1.72 \%$ \\
\hline All years & $9.31 \%$ & $0.88 \%$ & $1.25 \%$ & $0.54 \%$ & $0.19 \%$ & $4.82 \%$ & $2.12 \%$ \\
\hline
\end{tabular}


Table 4

Descriptive Data for Regression Variables

\begin{tabular}{lccccccc}
\hline \multicolumn{2}{l}{ Panel A. Descriptive Statistics for Control Variables } \\
\hline & Mean & Min & Q1 & Median & Q3 & Max & St. Dev. \\
\hline BETA & 1.05 & -0.16 & 0.52 & 0.91 & 1.37 & 3.82 & 0.76 \\
SIZE & 7.85 & 3.37 & 6.65 & 7.73 & 8.95 & 14.45 & 1.70 \\
BTM & 0.47 & 0.01 & 0.26 & 0.42 & 0.61 & 1.43 & 0.28 \\
LEV & 0.47 & 0.00 & 0.05 & 0.20 & 0.52 & 5.81 & 0.83 \\
LTG & 14.21 & 3.41 & 10.08 & 13.08 & 17.00 & 38.80 & 6.28 \\
DISP & 0.06 & 0.00 & 0.01 & 0.03 & 0.06 & 0.94 & 0.12 \\
\hline
\end{tabular}

Panel B. Pearson Correlation Coefficients between Regression Variables

\begin{tabular}{lccccccc}
\hline & $r_{A V G}$ & CSR_S & BETA & SIZE & BTM & LEV & LTG \\
\hline CSR_S & $-\mathbf{0 . 1 4}$ & & & & & & \\
BETA & 0.11 & -0.01 & & & & & \\
SIZE & -0.03 & 0.13 & -0.23 & & & & \\
BTM & 0.29 & -0.14 & -0.12 & 0.15 & & & \\
LEV & 0.24 & 0.00 & -0.10 & 0.43 & 0.32 & & \\
LTG & 0.04 & 0.00 & 0.41 & -0.38 & -0.36 & -0.27 & \\
DISP & 0.29 & -0.08 & 0.21 & -0.10 & 0.15 & 0.07 & 0.09 \\
\hline
\end{tabular}

This table presents descriptive statistics for the regression variables for the 12,915 firm-year sample observations between 1992 and 2007. Panel A provides the mean, minimum, first quartile, median, third quartile, maximum, and standard deviation of the control variables. Panel B shows Pearson pair-wise correlations between the regression variables. $r_{A V G}$ is the average implied cost of equity premium obtained from four models developed by Claus and Thomas (2001), Gebhardt, Lee, and Swaminathan (2001), Ohlson and Juettner-Nauroth (2005), and Easton (2004). Appendix A provides details on the implementation of the four models. Appendix $\mathrm{C}$ outlines definitions and data sources for the regression variables. Correlation coefficients in boldface are significant at the $1 \%$ level. 
Table 5

Univariate Tests

\begin{tabular}{|c|c|c|c|c|c|c|c|}
\hline \multicolumn{8}{|l|}{ Panel A. Means } \\
\hline & & $N$ & $r_{C T}$ & $r_{G L S}$ & $r_{\mathrm{OJ}}$ & $r_{E S}$ & $r_{A V G}$ \\
\hline$C S R \_S \geq$ median & $(1)$ & 8,065 & 3.76 & 3.59 & 5.40 & 5.42 & 4.54 \\
\hline$C S R \_S<$ median & (2) & 4,850 & 4.19 & 4.04 & 5.97 & 6.20 & 5.10 \\
\hline Difference & $(1)-(2)$ & & -0.43 & -0.45 & -0.57 & -0.78 & -0.56 \\
\hline T-Stat & & & $9.06^{* * *}$ & $7.87^{* * *}$ & $11.13^{* * *}$ & $11.45^{* * *}$ & $12.84^{* * *}$ \\
\hline \multicolumn{8}{|l|}{ Panel B. Medians } \\
\hline & & $N$ & $r_{C T}$ & $r_{G L S}$ & $r_{O J}$ & $r_{E S}$ & $r_{A V G}$ \\
\hline$C S R \_S \geq$ median & (1) & 8,065 & 3.52 & 3.54 & 5.01 & 4.72 & 4.25 \\
\hline$C S R \_S<$ median & (2) & 4,850 & 3.83 & 3.97 & 5.41 & 5.33 & 4.64 \\
\hline Difference & $(1)-(2)$ & & -0.31 & -0.43 & -0.4 & -0.61 & -0.39 \\
\hline Z-Stat & & & $9.63^{* * *}$ & $11.16^{* * *}$ & $11.73^{* * *}$ & $12.55^{\star * *}$ & $13.32^{* * *}$ \\
\hline \multicolumn{8}{|c|}{$\begin{array}{l}\text { This table presents mean (Panel A) and median (Panel B) comparison tests for individual and average cost of equity } \\
\text { premium estimates across subsamples of high (above median) and low (below median) CSR score (CSR_S). The total } \\
\text { sample includes 12,915 firm-years between } 1992 \text { and 2007. } r_{A V G} \text { is the average implied cost of equity premium } \\
\text { obtained from four models developed by Claus and Thomas (2001), Gebhardt, Lee, and Swaminathan (2001), Ohlson } \\
\text { and Juettner-Nauroth (2005), and Easton (2004), which we denote } r_{C T}, r_{G L S}, r_{O J} \text {, and } r_{E S} \text {, respectively. Appendix A } \\
\text { provides details on the implementation of the four models. }{ }^{* *} \text { denotes statistical significance at the } 1 \% \text { level. }\end{array}$} \\
\hline
\end{tabular}


Table 6

Corporate Social Responsibility and the Cost of Equity Capital

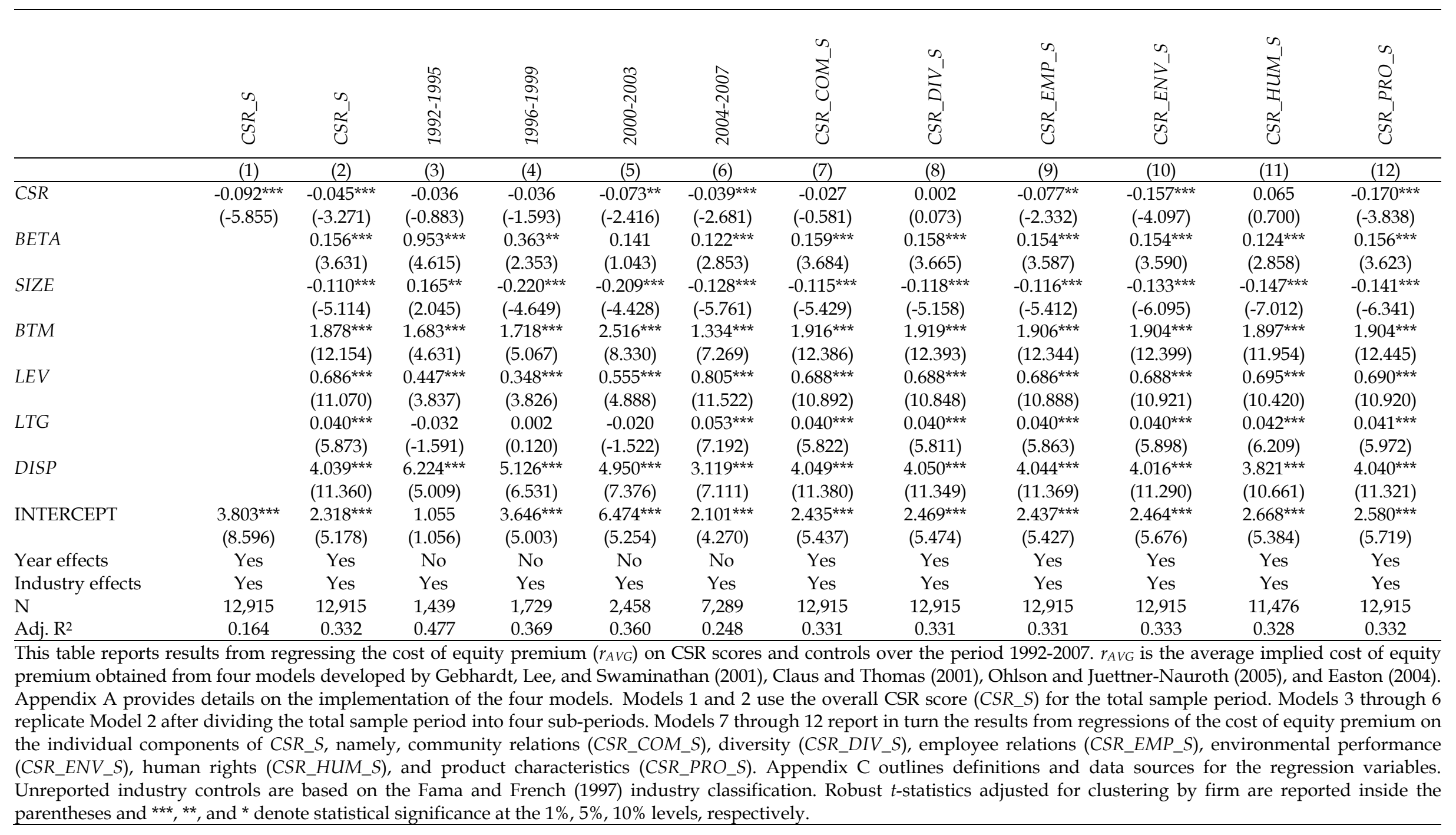


Table 7

Controversial Business Areas and the Cost of Equity Capital

\begin{tabular}{lccccccc}
\hline & CSR_CONTR & CSR_ALC & CSR_GAM & CSR_TOB & CSR_FIR & CSR_MIL & CSR_NUC \\
\hline CSR & $(1)$ & $(2)$ & $(3)$ & $(4)$ & $(5)$ & $(6)$ & $(7)$ \\
& $0.173^{*}$ & 0.157 & -0.127 & $1.180^{* * *}$ & 0.210 & 0.165 & $0.249^{* *}$ \\
BETA & $(1.893)$ & $(0.657)$ & $(-0.466)$ & $(2.792)$ & $(0.338)$ & $(1.352)$ & $(2.004)$ \\
& $0.165^{* * *}$ & $0.159^{* * *}$ & $0.158^{* * *}$ & $0.158^{* * *}$ & $0.144^{* * *}$ & $0.164^{* * *}$ & $0.158^{* * *}$ \\
SIZE & $(3.781)$ & $(3.679)$ & $(3.664)$ & $(3.676)$ & $(3.215)$ & $(3.751)$ & $(3.677)$ \\
& $-0.122^{* * *}$ & $-0.117^{* * *}$ & $-0.117^{* * *}$ & $-0.120^{* * *}$ & $-0.155^{* * *}$ & $-0.119^{* * *}$ & $-0.120^{* * *}$ \\
BTM & $(-5.620)$ & $(-5.488)$ & $(-5.426)$ & $(-5.589)$ & $(-7.397)$ & $(-5.572)$ & $(-5.532)$ \\
& $1.912^{* * *}$ & $1.918^{* * *}$ & $1.917^{* * *}$ & $1.908^{* * *}$ & $1.884^{* * *}$ & $1.918^{* * *}$ & $1.912^{* * *}$ \\
LEV & $(12.406)$ & $(12.436)$ & $(12.430)$ & $(12.399)$ & $(11.468)$ & $(12.455)$ & $(12.360)$ \\
& $0.688^{* * *}$ & $0.688^{* * *}$ & $0.688^{* * *}$ & $0.689^{* * *}$ & $0.741^{* * *}$ & $0.688^{* * *}$ & $0.690^{* * *}$ \\
LTG & $(10.888)$ & $(10.852)$ & $(10.849)$ & $(10.869)$ & $(11.131)$ & $(10.861)$ & $(10.883)$ \\
& $0.040^{* * *}$ & $0.040^{* * *}$ & $0.040^{* * *}$ & $0.039^{* * *}$ & $0.041^{* * *}$ & $0.040^{* * *}$ & $0.040^{* * *}$ \\
DISP & $(5.799)$ & $(5.812)$ & $(5.814)$ & $(5.795)$ & $(6.067)$ & $(5.823)$ & $(5.796)$ \\
& $4.058^{* * *}$ & $4.051^{* * *}$ & $4.050^{* * *}$ & $4.037^{* * *}$ & $3.615^{* * *}$ & $4.055^{* * *}$ & $4.053^{* * *}$ \\
INTERCEPT & $(11.393)$ & $(11.368)$ & $(11.365)$ & $(11.341)$ & $(9.563)$ & $(11.378)$ & $(11.372)$ \\
& $2.500^{* * *}$ & $2.463^{* * *}$ & $2.460^{* * *}$ & $2.489^{* * *}$ & $2.611^{* * *}$ & $2.475^{* * *}$ & $2.489^{* * *}$ \\
Year effects & $(5.585)$ & $(5.529)$ & $(5.517)$ & $(5.585)$ & $(4.991)$ & $(5.551)$ & $(5.557)$ \\
Industry effects & Yes & Yes & Yes & Yes & Yes & Yes & Yes \\
N & Yes & Yes & Yes & Yes & Yes & Yes & Yes \\
Adj. R & 12,915 & 12,915 & 12,915 & 12,915 & 10,195 & 12,915 & 12,915 \\
\hline & 0.331 & 0.331 & 0.331 & 0.332 & 0.311 & 0.331 & 0.331 \\
\hline
\end{tabular}

This table reports results from regressing the cost of equity premium $\left(r_{A V G}\right)$ on indicators for controversial business areas and controls over the period 1992-2007. $r_{A V G}$ is the average implied cost of equity premium obtained from four models developed by Gebhardt, Lee, and Swaminathan (2001), Claus and Thomas (2001), Ohlson and Juettner-Nauroth (2005), and Easton (2004). Appendix A provides details on the implementation of the four models. The controversial business areas are alcohol (CSR_ALC in Model 2), gambling (CSR_GAM in Model 3), tobacco (CSR_TOB in Model 4), firearms (CSR_FIR in Model 5), the military (CSR_MIL in Model 6), and nuclear power (CSR_NUC in Model 7). In Model 1 CSR_CONTR is a dummy variable taking the value of 1 for firms involved in any of the six controversial business areas. Appendix $C$ outlines definitions and data sources for the regression variables. Unreported industry controls are based on the Fama and French (1997) industry classification. Robust $t$-statistics adjusted for clustering by firm are reported inside the parentheses and $* * *, * *$, and * denote statistical significance at the $1 \%, 5 \%, 10 \%$ levels, respectively. 
Table 8

Corporate Social Responsibility and Individual and Alternative Cost of Equity Capital Estimates

\begin{tabular}{|c|c|c|c|c|c|c|c|c|}
\hline & \multicolumn{4}{|c|}{ Individual Cost of Equity Estimates } & \multicolumn{4}{|c|}{ Alternative Cost of Equity Estimates } \\
\hline & $r_{C T}$ & $r_{G L S}$ & $r_{\mathrm{OJ}}$ & $r_{E S}$ & $r_{F H G}$ & $r_{P E G 2}$ & $r_{P E G 5}$ & $E P R$ \\
\hline & $(1)$ & $(2)$ & $(3)$ & $(4)$ & $(5)$ & $(6)$ & $(7)$ & $(8)$ \\
\hline \multirow[t]{2}{*}{ CSR_S } & $-0.059^{* * *}$ & -0.027 & $-0.040^{* * *}$ & $-0.052^{* * *}$ & $-0.063^{* * *}$ & $-0.050^{* * *}$ & $-0.044^{* * *}$ & $-0.048^{* * *}$ \\
\hline & $(-3.873)$ & $(-1.393)$ & $(-2.775)$ & $(-2.720)$ & $(-4.610)$ & $(-2.773)$ & $(-3.471)$ & $(-4.267)$ \\
\hline \multirow[t]{2}{*}{ BETA } & 0.018 & $0.319 * * *$ & 0.013 & $0.274^{* * *}$ & -0.064 & $0.451^{* * *}$ & 0.017 & -0.006 \\
\hline & $(0.360)$ & $(4.654)$ & $(0.282)$ & $(4.547)$ & $(-1.451)$ & $(7.816)$ & $(0.345)$ & $(-0.155)$ \\
\hline \multirow[t]{2}{*}{ SIZE } & -0.031 & $-0.152^{* * *}$ & $-0.091^{* * *}$ & $-0.165^{\star * *}$ & -0.002 & $-0.182^{* * *}$ & $-0.067^{* * *}$ & $0.034^{*}$ \\
\hline & $(-1.236)$ & $(-5.438)$ & $(-3.515)$ & $(-5.380)$ & $(-0.067)$ & $(-6.609)$ & $(-2.877)$ & $(1.765)$ \\
\hline \multirow[t]{2}{*}{ BTM } & $0.517^{* * *}$ & $3.188^{* * *}$ & $1.481^{* * *}$ & $2.326^{* * *}$ & $1.220 * * *$ & $2.270 * * *$ & $1.204^{* * *}$ & $0.922 * * *$ \\
\hline & $(2.845)$ & $(12.778)$ & $(8.666)$ & $(10.960)$ & (7.756) & (11.859) & $(8.717)$ & $(7.716)$ \\
\hline \multirow[t]{2}{*}{$L E V$} & $0.762^{* * *}$ & $0.640^{* * *}$ & $0.613^{* * *}$ & $0.730^{* * *}$ & $0.765^{* * *}$ & $0.622^{* * *}$ & $0.531^{* * *}$ & $0.615^{* * *}$ \\
\hline & $(12.566)$ & $(9.704)$ & $(8.105)$ & $(7.671)$ & (11.190) & $(8.833)$ & (12.387) & $(14.472)$ \\
\hline \multirow[t]{2}{*}{ LTG } & $0.058^{* * *}$ & -0.015 & $0.084^{* * *}$ & $0.033^{* * *}$ & $0.052^{* * *}$ & $0.077^{* * *}$ & $0.340^{* * *}$ & $-0.086^{* * *}$ \\
\hline & $(7.548)$ & $(-1.579)$ & $(10.718)$ & $(3.491)$ & $(6.289)$ & $(9.202)$ & $(32.578)$ & $(-17.446)$ \\
\hline \multirow[t]{2}{*}{ DISP } & $-1.250 * * *$ & -0.138 & $5.943^{* * *}$ & $11.601^{* * *}$ & $-1.321^{* * *}$ & $11.172^{* * *}$ & $-1.587^{* * *}$ & $-6.259 * * *$ \\
\hline & $(-3.207)$ & $(-0.430)$ & (13.167) & (19.511) & $(-3.168)$ & $(22.101)$ & $(-5.607)$ & $(-34.542)$ \\
\hline \multirow[t]{2}{*}{ INTERCEPT } & $2.019^{* * *}$ & $2.057^{* * *}$ & $2.557^{* * *}$ & $2.639^{* * *}$ & 0.119 & $1.909^{* * *}$ & 0.179 & $5.350^{* * *}$ \\
\hline & $(3.839)$ & $(3.121)$ & $(5.670)$ & $(4.738)$ & $(0.269)$ & $(3.772)$ & $(0.397)$ & (19.633) \\
\hline Year effects & Yes & Yes & Yes & Yes & Yes & Yes & Yes & Yes \\
\hline Industry effects & Yes & Yes & Yes & Yes & Yes & Yes & Yes & Yes \\
\hline $\mathrm{N}$ & 12,915 & 12,915 & 12,915 & 12,915 & 12,914 & 12,881 & 12,699 & 12,915 \\
\hline Adj. $R^{2}$ & 0.167 & 0.257 & 0.275 & 0.359 & 0.264 & 0.428 & 0.516 & 0.457 \\
\hline \multicolumn{9}{|c|}{$\begin{array}{l}\text { This table presents results from regressing individual cost of equity premium estimates (Models 1-4) and } \\
\text { alternative cost of equity premium estimates (Models 5-8) on the overall CSR score (CSR_S) and controls over the } \\
\text { period 1992-2007. We estimate the cost of equity capital from applications developed by Claus and Thomas (2001) } \\
\text { in Model 1, Gebhardt, Lee, and Swaminathan (2001) in Model 2, Ohlson and Juettner-Nauroth (2005) in Model 3, } \\
\text { Easton (2004) in Model 4, the finite horizon Gordon model in Model 5, the risk premium implied by the Price- } \\
\text { Earnings-Growth (PEG) ratio based on one- and two-year-ahead earnings forecasts in Model } 6 \text { and four- and five- } \\
\text { year-ahead earnings forecasts in Model 7, and the earnings-to-price ratio in Model } 8 \text {. Appendix A provides details } \\
\text { on the implementation of the four models. Appendix C outlines definitions and data sources for the regression } \\
\text { variables. Unreported industry controls are based on the Fama and French (1997) industry classification. Robust } t \text { - } \\
\text { statistics adjusted for clustering by firm are reported inside the parentheses and } * * *, * * \text { and * denote statistical } \\
\text { significance at the } 1 \%, 5 \%, 10 \% \text { levels, respectively. }\end{array}$} \\
\hline
\end{tabular}


Table 9

Robustness to Analyst Forecast Optimism

\begin{tabular}{|c|c|c|c|c|c|c|c|c|c|}
\hline & & \multicolumn{4}{|c|}{ Forecast optimism bias less than $\mathrm{j}$ th percentile } & \multicolumn{4}{|c|}{ Long-term growth forecast less than $\mathrm{jth}$ percentile } \\
\hline & & $\mathrm{j}=95 \%$ & $\mathrm{j}=90 \%$ & $\mathrm{j}=75 \%$ & $\mathrm{j}=50 \%$ & $\mathrm{j}=95 \%$ & $\mathrm{j}=90 \%$ & $\mathrm{j}=75 \%$ & $\mathrm{j}=50 \%$ \\
\hline & & $(0.031)$ & $(0.017)$ & $(0.004)$ & $(0.000)$ & $(26.22)$ & $(22)$ & $(17)$ & $(13.09)$ \\
\hline & $(1)$ & $(2)$ & $(3)$ & $(4)$ & $(5)$ & $(6)$ & $(7)$ & $(8)$ & $(9)$ \\
\hline CSR_S & $(-3.383)$ & $(-3.163)$ & $(-2.850)$ & $(-2.916)$ & $(-2.275)$ & $(-3.197)$ & $(-3.169)$ & $(-2.827)$ & $(-1.787)$ \\
\hline \multirow[t]{2}{*}{ BETA } & $0.162^{* * *}$ & $0.124^{* * *}$ & $0.134^{* * *}$ & $0.122^{* * *}$ & $0.105^{*}$ & $0.193^{* * *}$ & $0.205^{* * *}$ & $0.212^{* * *}$ & $0.251^{* * *}$ \\
\hline & $(3.783)$ & $(2.969)$ & $(3.156)$ & $(2.632)$ & $(1.907)$ & $(4.378)$ & $(4.389)$ & $(3.669)$ & $(2.951)$ \\
\hline SIZE & $-0.084^{* * *}$ & $-0.089 * * *$ & $-0.075^{* * *}$ & $-0.066^{* * *}$ & $-0.082^{* * *}$ & $-0.115^{* * *}$ & $-0.106^{* * *}$ & $-0.098^{* * *}$ & $-0.059 * *$ \\
\hline \multirow[t]{2}{*}{ BTM } & $1.743^{* * *}$ & $1.858^{* * *}$ & $1.796^{* * *}$ & $1.740^{* * *}$ & $1.686^{* * *}$ & $1.833^{* * *}$ & $1.794^{* * *}$ & $1.704^{* * *}$ & $1.360 * * *$ \\
\hline & $(11.458)$ & $(12.436)$ & (11.853) & $(10.969)$ & $(9.089)$ & (11.553) & $(10.964)$ & $(9.778)$ & $(6.412)$ \\
\hline \multirow[t]{2}{*}{$L E V$} & $0.586^{* * *}$ & $0.607^{* * *}$ & $0.592^{* * *}$ & $0.567^{* * *}$ & $0.542^{* * *}$ & $0.667^{* * *}$ & $0.653^{* * *}$ & $0.632^{* * *}$ & $0.592^{* * *}$ \\
\hline & $(10.847)$ & (10.972) & (10.502) & $(9.851)$ & $(8.640)$ & $(10.922)$ & $(10.581)$ & $(10.232)$ & $(8.655)$ \\
\hline \multirow[t]{2}{*}{ LTG } & $0.041^{* * *}$ & $0.043^{* * *}$ & $0.042^{* * *}$ & $0.038^{* * *}$ & $0.032^{* * *}$ & $0.027^{* * *}$ & $0.025^{\star * *}$ & $0.024^{*}$ & 0.026 \\
\hline & $(6.004)$ & $(6.326)$ & $(5.965)$ & $(5.083)$ & $(4.049)$ & $(3.434)$ & $(2.736)$ & $(1.879)$ & $(1.282)$ \\
\hline \multirow[t]{2}{*}{ DISP } & $3.285^{* * *}$ & $3.302 * * *$ & $3.226 * * *$ & $3.391^{* * *}$ & $3.403^{* * *}$ & $4.461^{* * *}$ & $4.629^{* * *}$ & $5.058^{* * *}$ & $6.006^{* * *}$ \\
\hline & (10.127) & $(9.300)$ & $(8.518)$ & $(7.960)$ & $(8.328)$ & (11.425) & (11.051) & (10.704) & $(10.470)$ \\
\hline \multirow[t]{2}{*}{ INTERCEPT } & $2.263^{* * *}$ & $2.300^{* * *}$ & $2.257^{* * *}$ & $1.995^{\star * *}$ & $1.829^{* * *}$ & $2.498^{* * *}$ & $2.385^{* * *}$ & $2.309^{* * *}$ & 1.078 \\
\hline & $(5.849)$ & $(6.656)$ & $(6.529)$ & $(5.751)$ & $(4.768)$ & $(5.385)$ & $(5.006)$ & $(4.344)$ & (1.403) \\
\hline Year effects & Yes & Yes & Yes & Yes & Yes & Yes & Yes & Yes & Yes \\
\hline Industry effects & Yes & Yes & Yes & Yes & Yes & Yes & Yes & Yes & Yes \\
\hline $\mathrm{N}$ & 12,290 & 11,676 & 11,061 & 9,217 & 5,890 & 12,270 & 11,603 & 9,670 & 6,461 \\
\hline Adj. $R^{2}$ & 0.376 & 0.326 & 0.324 & 0.335 & 0.326 & 0.344 & 0.351 & 0.368 & 0.379 \\
\hline
\end{tabular}

This table examines the robustness of the results in Table 6, Model 2 to analyst forecast optimism. The dependent variable $r_{A V G}$ is the average implied cost of equity premium obtained from four models developed by Gebhardt, Lee, and Swaminathan (2001), Claus and Thomas (2001), Ohlson and Juettner-Nauroth (2005), and Easton (2004). Appendix A provides details on the implementation of the four models. Model 1 controls for forecast optimism bias (FBIAS). Models 2 to 5 exclude observations in the top 5\%, 10\%, 25\%, and 50\% of the FBIAS distribution, respectively. Models 6 to 9 exclude observations in the top 5\%,10\%, 25\%, and 50\% of the long-term growth forecast distribution (LTG), respectively. Appendix C outlines definitions and data sources for the regression variables. Unreported industry controls are based on the Fama and French (1997) industry classification. Robust $t$-statistics adjusted for clustering by firm are reported inside the parentheses and $* * * * *$, and * denote statistical significance at the $1 \%, 5 \%, 10 \%$ levels, respectively. 
Table 10

Robustness to Analyst Forecast Sluggishness

\begin{tabular}{|c|c|c|c|c|}
\hline & (1) & (2) & (3) & (4) \\
\hline$\overline{C S R} \_S$ & $\begin{array}{c}-0.042^{* * *} \\
(-2987)\end{array}$ & $-0.045^{* * *}$ & $\begin{array}{c}-0.046^{* * *} \\
(-3306)\end{array}$ & $-0.048^{* * *}$ \\
\hline BETA & $\begin{array}{c}0.015 \\
(0.347)\end{array}$ & $\begin{array}{c}0.131^{* * *} \\
(3.092)\end{array}$ & $\begin{array}{c}0.133^{* * *} \\
(3.077)\end{array}$ & $\begin{array}{c}0.152^{* * *} \\
(3.494)\end{array}$ \\
\hline SIZE & $\begin{array}{c}-0.082^{* * *} \\
(-3.789)\end{array}$ & $\begin{array}{c}-0.103^{* * *} \\
(-4.823)\end{array}$ & $\begin{array}{c}-0.097^{* * *} \\
(-4.471)\end{array}$ & $\begin{array}{c}-0.102^{* * *} \\
(-4.696)\end{array}$ \\
\hline BTM & $\begin{array}{l}2.223^{* * *} \\
(13.905)\end{array}$ & $\begin{array}{l}1.968^{* * *} \\
(12.632)\end{array}$ & $\begin{array}{l}1.947^{* * *} \\
(12.410)\end{array}$ & $\begin{array}{l}1.705^{* * *} \\
(10.881)\end{array}$ \\
\hline LEV & $\begin{array}{l}0.750^{* * *} \\
(11.765)\end{array}$ & $\begin{array}{l}0.721^{* * *} \\
(11.224)\end{array}$ & $\begin{array}{l}0.736^{* \star *} \\
(11.368)\end{array}$ & $\begin{array}{l}0.711^{* * *} \\
(11.236)\end{array}$ \\
\hline LTG & $\begin{array}{c}0.055^{* * *} \\
(7.857)\end{array}$ & $\begin{array}{c}0.045^{* * *} \\
(6.632)\end{array}$ & $\begin{array}{c}0.047^{* * *} \\
(6.872)\end{array}$ & $\begin{array}{c}0.049^{* * *} \\
(7.141)\end{array}$ \\
\hline DISP & $\begin{array}{c}2.963^{* * * *} \\
(9.049)\end{array}$ & $\begin{array}{l}3.840^{* * *} \\
(10.869)\end{array}$ & $\begin{array}{l}3.687^{* * *} \\
(10.394)\end{array}$ & $\begin{array}{l}3.616^{* * *} \\
(10.100)\end{array}$ \\
\hline MOM3 & & $\begin{array}{l}-3.051^{* * *} \\
(-19.486)\end{array}$ & & \\
\hline MOM6 & & & $\begin{array}{l}-2.281^{* * *} \\
(-20.414)\end{array}$ & \\
\hline MOM12 & & & & $\begin{array}{l}-1.177^{* * *} \\
(-16.005)\end{array}$ \\
\hline INTERCEPT & $\begin{array}{c}2.201^{* * *} \\
(5.432)\end{array}$ & $\begin{array}{c}2.493^{* * *} \\
(5.523)\end{array}$ & $\begin{array}{c}2.414^{* * *} \\
(5.348)\end{array}$ & $\begin{array}{c}2.399^{* * *} \\
(5.363)\end{array}$ \\
\hline Year effects & Yes & Yes & Yes & Yes \\
\hline Industry effects & Yes & Yes & Yes & Yes \\
\hline $\mathrm{N}$ & 12,879 & 12,900 & 12,900 & 12,900 \\
\hline Adj. $R^{2}$ & 0.363 & 0.363 & 0.367 & 0.355 \\
\hline
\end{tabular}

This table examines the robustness of the results in Table 6, Model 2 to analyst forecast sluggishness. The dependent variable $r_{A V G}$ is the average implied cost of equity premium obtained from four models developed by Gebhardt, Lee, and Swaminathan (2001), Claus and Thomas (2001), Ohlson and Juettner-Nauroth (2005), and Easton (2004). Appendix A provides details on the implementation of the four models. Model 1 re-estimates the implied cost of equity using January-end prices instead of June-end prices. Models 2 through 4 control for price momentum computed as the compounded returns over the past 3, 6, and 12 months, respectively. Appendix $\mathrm{C}$ outlines definitions and data sources for the regression variables. Unreported industry controls are based on the Fama and French (1997) industry classification. Robust tstatistics adjusted for clustering by firm are reported inside the parentheses and ***, **, and * denote statistical significance at the $1 \%, 5 \%, 10 \%$ levels, respectively. 
Table 11

Robustness to Endogeneity

\begin{tabular}{|c|c|c|c|c|c|c|c|}
\hline & $V A R=I N S T$ & $\begin{array}{c}\text { VAR }= \\
\text { CEO_INC }\end{array}$ & $V A R=E I$ & $A R=A N A$ & $V A R=K Z$ & IV & GMM \\
\hline & (1) & (2) & (3) & (4) & (5) & (6) & (7) \\
\hline CSR_S & $\begin{array}{c}-0.033^{* *} \\
(-2.546)\end{array}$ & $\begin{array}{c}-0.048^{\star * *} \\
(-3.076)\end{array}$ & $\begin{array}{c}-0.039^{* \star *} \\
(-2.734)\end{array}$ & $\begin{array}{c}-0.042^{* * *} \\
(-3.119)\end{array}$ & $\begin{array}{c}-0.054^{* * *} \\
(-3.749)\end{array}$ & $\begin{array}{c}-0.090^{* *} \\
(-1.989)\end{array}$ & $\begin{array}{l}-0.080^{\star *} \\
(-2.387)\end{array}$ \\
\hline BETA & $\begin{array}{c}0.189^{* * *} \\
(4.370)\end{array}$ & $\begin{array}{l}0.115^{* *} \\
(2.133)\end{array}$ & $\begin{array}{c}0.139^{\star * *} \\
(2.772)\end{array}$ & $\begin{array}{c}0.198^{* * *} \\
(4.656)\end{array}$ & $\begin{array}{l}0.107^{* *} \\
(2.375)\end{array}$ & $\begin{array}{c}0.153^{* * *} \\
(3.557)\end{array}$ & $\begin{array}{c}0.371^{* * *} \\
(5.043)\end{array}$ \\
\hline SIZE & $\begin{array}{c}0.260^{* * *} \\
(4.910)\end{array}$ & $\begin{array}{l}-0.049^{*} \\
(-1.783)\end{array}$ & $\begin{array}{c}-0.081^{* * *} \\
(-3.151)\end{array}$ & $\begin{array}{c}-0.012 \\
(-0.410)\end{array}$ & $\begin{array}{c}-0.166^{* * *} \\
(-7.070)\end{array}$ & $\begin{array}{c}-0.102^{* * *} \\
(-4.494)\end{array}$ & $\begin{array}{l}0.228^{* * *} \\
(10.612)\end{array}$ \\
\hline BTM & $\begin{array}{c}1.343^{* * *} \\
(7.696)\end{array}$ & $\begin{array}{l}2.045^{* \star *} \\
(11.118)\end{array}$ & $\begin{array}{l}1.932^{* \star *} \\
(11.284)\end{array}$ & $\begin{array}{l}1.746^{* * *} \\
(10.971)\end{array}$ & $\begin{array}{l}1.847^{* * *} \\
(11.430)\end{array}$ & $\begin{array}{l}1.837^{* * *} \\
(11.659)\end{array}$ & $\begin{array}{l}3.304^{* * *} \\
(12.225)\end{array}$ \\
\hline LEV & $\begin{array}{l}0.578^{\star \star *} \\
(9.595)\end{array}$ & $\begin{array}{l}0.538^{* \star *} \\
(7.296)\end{array}$ & $\begin{array}{c}0.628^{* * *} \\
(9.239)\end{array}$ & $\begin{array}{l}0.645^{* \star *} \\
(10.396)\end{array}$ & $\begin{array}{c}0.627^{* * *} \\
(6.906)\end{array}$ & $\begin{array}{l}0.684^{* * *} \\
(11.218)\end{array}$ & $\begin{array}{c}0.634^{* * *} \\
(5.974)\end{array}$ \\
\hline LTG & $\begin{array}{c}0.046^{* \star *} \\
(6.853)\end{array}$ & $\begin{array}{c}0.062^{* * *} \\
(6.577)\end{array}$ & $\begin{array}{c}0.040^{\star * *} \\
(4.915)\end{array}$ & $\begin{array}{c}0.045^{* \star *} \\
(6.654)\end{array}$ & $\begin{array}{c}0.035^{* * *} \\
(4.956)\end{array}$ & $\begin{array}{c}0.040^{* * *} \\
(5.914)\end{array}$ & $\begin{array}{l}0.116^{* * *} \\
(13.334)\end{array}$ \\
\hline DISP & $\begin{array}{l}3.818^{* * *} \\
(10.932)\end{array}$ & $\begin{array}{l}4.586^{* * *} \\
(10.936)\end{array}$ & $\begin{array}{l}4.460^{* * *} \\
(11.558)\end{array}$ & $\begin{array}{l}4.055^{* * *} \\
(11.363)\end{array}$ & $\begin{array}{l}3.857^{* * *} \\
(11.454)\end{array}$ & $\begin{array}{l}4.031^{* * *} \\
(11.334)\end{array}$ & $\begin{array}{c}4.633^{* * *} \\
(6.682)\end{array}$ \\
\hline$V A R$ & $\begin{array}{c}-0.876^{\star \star *} \\
(-8.156)\end{array}$ & $\begin{array}{c}-1.047^{* * *} \\
(-7.017)\end{array}$ & $\begin{array}{c}0.009 \\
(0.396)\end{array}$ & $\begin{array}{c}-0.340^{* * *} \\
(-5.462)\end{array}$ & $\begin{array}{c}0.160^{* * *} \\
(4.227)\end{array}$ & & \\
\hline $\operatorname{Lag}\left(r_{A V G}\right)$ & & & & & & & $\begin{array}{c}-0.401^{\text {*** }}(-7.241)\end{array}$ \\
\hline INTERCEPT & $\begin{array}{l}4.055^{* * *} \\
(8.146)\end{array}$ & $\begin{array}{c}2.084^{* * *} \\
(3.802)\end{array}$ & $\begin{array}{c}2.233^{* * *} \\
(4.585)\end{array}$ & $\begin{array}{c}2.217^{* * *} \\
(5.150)\end{array}$ & $\begin{array}{c}2.629^{* * *} \\
(4.971)\end{array}$ & $\begin{array}{c}2.169^{* * *} \\
(4.634)\end{array}$ & \\
\hline Year effects & Yes & Yes & Yes & Yes & Yes & Yes & Yes \\
\hline Industry effects & Yes & Yes & Yes & Yes & Yes & Yes & No \\
\hline $\mathrm{N}$ & 12,903 & 7,813 & 10,499 & 12,915 & 10,692 & 12,914 & 9,603 \\
\hline Adj. $R^{2}$ & 0.342 & 0.381 & 0.356 & 0.336 & 0.341 & 0.334 & \\
\hline
\end{tabular}

This table examines the robustness of the results in Table 6, Model 2 to omitted variables and reverse causality bias. The dependent variable $r_{A V G}$ is the average implied cost of equity premium obtained from four models developed by Gebhardt, Lee, and Swaminathan (2001), Claus and Thomas (2001), Ohlson and Juettner-Nauroth (2005), and Easton (2004). Appendix A provides details on the implementation of the four models. Models 1 through 5 separately include as an additional control (VAR) the logarithm of one plus the number of institutional investors (INST), the fraction of CEO compensation arising from a $1 \%$ increase in the stock price (CEO_INC), Bebchuk et al.'s (2009) antitakeover provisions index (EI), the logarithm of one plus the number of analysts following the firm (ANA), and Kaplan and Zingales' (1997) index of financial constraints (KZ), respectively. Model 6 uses the instrumental estimation approach. Model 7, which includes the lagged risk premium $\left(\operatorname{Lag}\left(r_{A V G}\right)\right)$ as an explanatory variable, is estimated using the system GMM technique after Blundell and Bond (1998). Appendix C outlines definitions and data sources for the regression variables. Unreported industry controls are based on the Fama and French (1997) industry classification. Robust $t$-statistics adjusted for clustering by firm are reported inside the parentheses and ***, **, and * denote statistical significance at the $1 \%, 5 \%, 10 \%$ levels, respectively. 